\title{
Phylogeography of the neotropical Anopheles triannulatus complex (Diptera: Culicidae) supports deep structure and complex patterns
}

Marta Moreno ${ }^{1,13^{*}}$, Sara Bickersmith ${ }^{1}$, Wesley Harlow ${ }^{1}$, Jessica Hildebrandt', Sascha N McKeon ${ }^{1,2}$,

Teresa Fernandes Silva-do-Nascimento ${ }^{3}$, Jose R Loaiza ${ }^{4}$, Freddy Ruiz ${ }^{5}$, Ricardo Lourenço-de-Oliveira ${ }^{3}$,

Maria AM Sallum ${ }^{6}$, Eduardo S Bergo ${ }^{7}$, Gary N Fritz ${ }^{8}$, Richard C Wilkerson ${ }^{5}$, Yvonne M Linton ${ }^{5}$, Maria J Dantur Juri ${ }^{9}$, Yadira Rangel ${ }^{10}$, Marinete M Póvoa ${ }^{11}$, Lina A Gutiérrez-Builes ${ }^{12}$, Margarita M Correa ${ }^{12}$ and Jan E Conn ${ }^{1,2}$

\begin{abstract}
Background: The molecular phylogenetic relationships and population structure of the species of the Anopheles triannulatus complex: Anopheles triannulatus s.s., Anopheles halophylus and the putative species Anopheles triannulatus $C$ were investigated.
\end{abstract}

Methods: The mitochondrial COI gene, the nuclear white gene and rDNA ITS2 of samples that include the known geographic distribution of these taxa were analyzed. Phylogenetic analyses were performed using Bayesian inference, Maximum parsimony and Maximum likelihood approaches.

Results: Each data set analyzed separately yielded a different topology but none provided evidence for the separation of An. halophylus and An. triannulatus C, consistent with the hypothesis that the two are undergoing incipient speciation. The phylogenetic analyses of the white gene found three main clades, whereas the statistical parsimony network detected only a single metapopulation of Anopheles triannulatus s.l. Seven COl lineages were detected by phylogenetic and network analysis. In contrast, the network, but not the phylogenetic analyses, strongly supported three ITS2 groups. Combined data analyses provided the best resolution of the trees, with two major clades, Amazonian (clade I) and trans-Andean + Amazon Delta (clade II). Clade I consists of multiple subclades: An. halophylus + An. triannulatus C; trans-Andean Venezuela; central Amazonia + central Bolivia; Atlantic coastal lowland; and Amazon delta. Clade II includes three subclades: Panama; cis-Andean Colombia; and cisVenezuela. The Amazon delta specimens are in both clades, likely indicating local sympatry. Spatial and molecular variance analyses detected nine groups, corroborating some of subclades obtained in the combined data analysis.

Conclusion: Combination of the three molecular markers provided the best resolution for differentiation within An. triannulatus S.S. and An. halophylus and C. The latest two species seem to be very closely related and the analyses performed were not conclusive regarding species differentiation. Further studies including new molecular markers would be desirable to solve this species status question. Besides, results of the study indicate a trans-Andean origin for An. triannulatus s.l. The potential implications for malaria epidemiology remain to be investigated.

Keywords: Anopheles triannulatus s.s., Anopheles halophylus, Anopheles triannulatus C, phylogeography, COl gene, White gene, ITS2

\footnotetext{
* Correspondence: mmorenoleirana@ucsd.edu

${ }^{1}$ New York State Department of Health, Wadsworth Center, Griffin

Laboratory, Albany, NY, USA

${ }^{13}$ Present address: Division Infectious Diseases University of California San

Diego, George Palade Labs, School of Medicine, 9500 Gilman Drive, MC 0741

La Jolla, CA 92093, USA

Full list of author information is available at the end of the article
} 


\section{Background}

Neotropical anophelines have shown an extraordinary diversity and complexity due, in part, to the capability of dipterans to adapt to and utilize a broad variety of ecological niches [1]. The subgenus Nyssorhynchus provides an example of extensive morphological and genetic variation within taxa, and several studies have focused on the processes driving this differentiation. Some hypotheses are related to climatic changes that occurred in different epochs, provoking drastic modifications to the habitats of different organisms [2,3]. However, this remains controversial because of the paucity of available evidence-based data [4-6]. Furthermore, factors affecting speciation and population differentiation, such as ecology, behaviour and genetics, evolve at different rates and are not necessarily congruent [7].

Some of these taxa, estimated to be $10 \%$ of all anophelines, are directly responsible for malaria parasite transmission and their accurate identification is necessary for the implementation of effective control strategies. Understanding the current distribution of species, investigating past or recent demographic events (population growth or contraction), gene flow, as well as human interventions (exploitation of new ecological niches, introduction of non endemic species, among others), can provide powerful tools and valuable predictors for the management of pathogens transmitted by anophelines.

Anopheles triannulatus s.l., subgenus Nyssorhynchus, [8] was first described from adult females in central Brazil and subsequently reported in Central America (Costa Rica, Nicaragua and Panama), in the majority of South American countries [9,10], and recently in some Caribbean islands [11]. This species has been previously described under different names (syn.bachmanni Petrocchi, syn. chagasi Galvao, syn. cuyabensis Neiva and Pinto, syn. davisi Paterson and Shannon, syn. perezi Shannon and Del Ponte). Morphological variation was later considered intraspecific and attributed to adaptation to different habitats [9,12-18]. However, recent investigations based on morphological characters of the male genitalia and immature stages led to the designation of a new species, Anopheles halophylus, and elevated the status from polymorphic species to complex, (i.e. the Anopheles triannulatus complex) [18-20].

Genetic distance analysis of allozymes and RAPD detected a third species, An. triannulatus $\mathrm{C}$, and showed that An. halophylus and An. triannulatus species $C$ formed a reciprocally monophyletic group [20]. Apart from this preliminary finding, very little is known about the phylogenetic relationships of members of the An. triannulatus complex, except for the results of analysis of sequences of cpr and timeless genes [21], which confirmed previous findings and suggested that An. halophylus and $A n$. triannulatus $\mathrm{C}$ are in the process of incipient speciation.
Seasonal population density and behavioral differences have also been reported within the complex, for example, potential species-specific preferences for different larval habitats of species that occur in sympatry, e.g., $A n$. halophylus and An. triannulatus species C [19,22].

An. triannulatus s.l. has been incriminated in human malaria transmission in different regions of Brazil [23-26]), and probably Peru and Venezuela [27,28], although the role of each species within the complex remains unknown. However, zoophilic and exophilic behaviour has been much commonly reported in Brazil [29-32].

The study of sibling species is aggravated by the difficulty of identification based exclusively on morphological characters when key traits, especially in adult females, may exhibit great phenotypic plasticity [33]. Nowadays, DNA sequences are an essential tool for delineating and identifying species, as well as for gathering information about the genetic variation within species complexes. The mitochondrial gene cytochrome oxidase subunit $1(C O I)$ is usually informative in phylogenetic reconstruction and geographic variability [34-36]. To represent the nuclear genome the singlecopy white gene was chosen $[37,38]$. The ribosomal DNA (r-DNA) internal transcribed spacer 2 (ITS2) was used because it plays an important role in distinguishing cryptic anopheline species [39,40].

The major objective of this study was to reconstruct and clarify the evolutionary relationships based on mtDNA and nuclear sequences, to illustrate the demographic history at the population level, and to provide information on the distribution of An. triannulatus s.l. in several countries across its range. The information obtained would be useful to distinguish the species and help to focus scarce vector control resources on species involved in malaria transmission.

\section{Methods \\ Sampling}

Mosquitoes were collected from 31 localities in eight countries, including Argentina, Bolivia, Brazil, Colombia, Ecuador, Panama, Trinidad-Tobago and Venezuela (Table 1) covering a wide range of the reported species distribution (Figure 1). Adult mosquitoes were collected outdoors by human landing catches (protocols approved by the Institutional Review Board of the New York State Department of Health, University of Antioquia, University of Florida and University of Vermont), except specimens from Argentina and Brazil that were collected by CDC light traps or horse-baited Shannon traps, respectively. Some specimens included in the analysis from Brazil (donated by MAMS) were collected as either larvae or pupae and kept in the laboratory to obtain adults linked with larval and/or pupal exuviae. Two topotype specimens 
Table 1 Summary data for collection localities and sample information of the Anopheles triannulatus complex

\begin{tabular}{|c|c|c|c|c|c|c|c|}
\hline \multirow[t]{2}{*}{ Site No. } & \multirow[t]{2}{*}{ Country } & \multirow[t]{2}{*}{ Locality } & \multicolumn{3}{|c|}{$N$} & \multirow[t]{2}{*}{ Coordinates } & \multirow[t]{2}{*}{ Collector } \\
\hline & & & $\begin{array}{c}\mathrm{COI} \\
(n=326)\end{array}$ & $\begin{array}{c}\text { white } \\
(n=85)\end{array}$ & $\begin{array}{c}\text { ITS2 } \\
(n=34)\end{array}$ & & \\
\hline 1 & Argentina & Yuto Farm (FY) & 23 & 3 & 1 & $23^{\circ} 63^{\prime} \mathrm{S} / 64^{\circ} 46^{\prime} \mathrm{W}$ & MJD \\
\hline 2 & & Lake Yuto (LY) & 3 & 0 & 0 & $23^{\circ} 38^{\prime} \mathrm{S} / 64^{\circ} 27^{\prime} \mathrm{W}$ & MJD \\
\hline 3 & Bolivia & Guayaramerin (GU) & 4 & 0 & 0 & $10^{\circ} 49^{\prime} \mathrm{S} / 65^{\circ} 21^{\prime} \mathrm{W}$ & JEC \\
\hline 4 & & Puerto Villaroel (PV) & 10 & 2 & 2 & $16^{\circ} 52^{\prime} \mathrm{S} / 64^{\circ} 46^{\prime} \mathrm{W}$ & JEC \\
\hline 5 & Brazil & Ceara (CE) & 2 & 2 & 0 & $5^{\circ} 05^{\prime} \mathrm{S} / 40^{\circ} 23^{\prime} \mathrm{W}$ & TFS \\
\hline 6 & & Espirito Santo (ES) & 1 & 0 & 0 & $1^{\circ} 15^{\prime} \mathrm{N} / 50^{\circ} 54^{\prime} \mathrm{W}$ & TFS \\
\hline 7 & & Fazenda S. Joao (MT) & 2 & 1 & 1 & $16^{\circ} 57^{\prime} \mathrm{S} / 56^{\circ} 36^{\prime} \mathrm{W}$ & TFS \\
\hline 8 & & Monte Negro (RO) & 5 & 2 & 0 & $10^{\circ} 15^{\prime} \mathrm{S} / 63^{\circ} 19^{\prime} \mathrm{W}$ & MAMS/ESB \\
\hline 9 & & Aquidauana (Pantanal do Rio Negro) (AQU) & 6 & 4 & 0 & $19^{\circ} 29^{\prime} \mathrm{S} / 55^{\circ} 36^{\prime} \mathrm{W}$ & MAMS/ESB \\
\hline 10 & & Inubia Paulista (SP) & 6 & 2 & 0 & $21^{\circ} 39^{\prime} \mathrm{S} / 50^{\circ} 56^{\prime} \mathrm{W}$ & MAMS/ESB \\
\hline 11 & & Camacan/Santa Luzia (Bahia) (BA) & 7 & 3 & 0 & $15^{\circ} 25^{\prime} \mathrm{S} / 39^{\circ} 32^{\prime} \mathrm{W}$ & MAMS/ESB \\
\hline 12 & & Coronel Pacheco (Minas Gerais) (MG) & 6 & 3 & 0 & $21^{\circ} 38^{\prime} \mathrm{S} / 43^{\circ} 19^{\prime} \mathrm{W}$ & MAMS/ESB \\
\hline 13 & & Lagoa da Confusao (Tocantins) (TO) & 6 & 2 & 0 & $10^{\circ} 35^{\prime} \mathrm{S} / 49^{\circ} 41^{\prime} \mathrm{W}$ & MAMS/ESB \\
\hline 14 & & Itaituba (ITB) & 5 & 1 & 1 & $4^{\circ} 15^{\prime} \mathrm{S} / 55^{\circ} 59^{\prime} \mathrm{W}$ & MAMP/JEC \\
\hline 15 & & Oswaldo Cruz (OC) & 19 & 7 & 3 & $8^{\circ} 00^{\prime} \mathrm{S} / 35^{\circ} 00^{\prime} \mathrm{W}$ & MAMP/JEC \\
\hline 16 & & Salobra (MS) & 20 & 9 & 4 & $20^{\circ} 12^{\prime} \mathrm{S} / 56^{\circ} 29^{\prime} \mathrm{W}$ & TFS \\
\hline 17 & & Silva Jardim (RJ) & 2 & 2 & 1 & $22^{\circ} 39^{\prime} \mathrm{S} / 42^{\circ} 23^{\prime} \mathrm{W}$ & TFS \\
\hline 18 & & Tartarugalzinho (TAR) & 23 & 4 & 1 & $1^{\circ} 30^{\prime} \mathrm{N} / 50^{\circ} 54^{\prime} \mathrm{W}$ & MAMP/JEC \\
\hline 19 & Colombia & Monitos (MO) & 22 & 6 & 4 & $9^{\circ} 13^{\prime} \mathrm{N} / 76^{\circ} 08^{\prime} \mathrm{W}$ & NN/PA \\
\hline 20 & & Santa Rosa de Lima (SO) & 27 & 5 & 4 & $10^{\circ} 26^{\prime} \mathrm{N} / 75^{\circ} 21 \mathrm{~W}$ & NN/JP \\
\hline 21 & & Leticia, km12 (COSW) & 10 & 4 & 3 & $04^{\circ} 6 \mathrm{~S} / 69^{\circ} 57^{\prime} \mathrm{W}$ & $J F R$ \\
\hline 22 & & Tibu (COL) & 3 & 0 & 0 & $08^{\circ} 38^{\prime} \mathrm{N} / 72^{\circ} 44^{\prime} \mathrm{W}$ & $J F R$ \\
\hline 23 & Ecuador & Juan Montalvo (JM) & 6 & 1 & 1 & $0^{\circ} 50^{\prime} \mathrm{N} / 78^{\circ} 51^{\prime} \mathrm{W}$ & GNF \\
\hline 24 & Panama & Bayano (BAY) & 7 & 1 & 1 & $9^{\circ} 07^{\prime} \mathrm{N} / 79^{\circ} 01^{\prime} \mathrm{W}$ & $J R L$ \\
\hline 25 & & Gamboa (GAM) & 29 & 4 & 2 & $9^{\circ} 07^{\prime} \mathrm{N} / 79^{\circ} 42^{\prime} \mathrm{W}$ & $J R L$ \\
\hline 26 & & Meteti (MET) & 17 & 2 & 1 & $8^{\circ} 30^{\prime} \mathrm{N} / 79^{\circ} 58^{\prime} \mathrm{W}$ & $J R L$ \\
\hline 27 & Venezuela & Boconoito (BOC) & 6 & 2 & 0 & $8^{\circ} 50^{\prime} \mathrm{N} / 69^{\circ} 58^{\prime} \mathrm{W}$ & $\mathrm{JEC} / \mathrm{YR}$ \\
\hline 28 & & Cano Amarillo (CAM) & 15 & 6 & 2 & $8^{\circ} 43^{\prime} \mathrm{N} / 71^{\circ} 34^{\prime} \mathrm{W}$ & $\mathrm{JEC} / \mathrm{YR}$ \\
\hline 29 & & Casigua Zulia (CAS) & 25 & 4 & 2 & $8^{\circ} 44^{\prime} \mathrm{N} / 72^{\circ} 30^{\prime} \mathrm{W}$ & $\mathrm{JEC} / \mathrm{YR}$ \\
\hline 30 & & La Veguita (VG) & 6 & 1 & 0 & $8^{\circ} 52^{\prime} \mathrm{N} / 70^{\circ} 0^{\prime} \mathrm{W}$ & JEC/EB \\
\hline 31 & Trinidad-Tobago & St.Andrew/St.David, Valencia (TRI) & 2 & 0 & 0 & $10^{\circ} 39^{\prime} \mathrm{N} / 61^{\circ} 09^{\prime} \mathrm{W}$ & RCW \\
\hline
\end{tabular}

Salobra (16) and Fazenda S. João (7), in Brazil, are the type localities for An. halophylus and An. triannulatus $C$, respectively. $N$, sample size of each of the genes sequenced; MJD, MJ Dantur; JEC, JE Conn; TFS, T Fernandes-da-Silva; MAMS, MA Mureb-Sallum; ESB, ES Bergo; MAMP: MAM Povoa; NN, N Naranjo; PA, P Aviles; JP, J Pinto; JFR, JF Ruiz; GNF, GN Fritz; JRL, JR Loaiza; YR: Y Rangel; EB: E Brown; RCW, RC Wilkerson.

of Anopheles halophylus and Anopheles triannulatus C (Salobra, Brazil) and An. triannulatus s.s. were included in the analysis. Specimens were morphologically identified using the available identification keys $[9,17]$. Identification of An. halophylus, An. triannulatus $\mathrm{C}$ and some representatives of $A n$. triannulatus s.s. was based on morphological characters and the Mpi diagnostic allozyme [20]. Mosquitoes were then stored in either 95\% ethanol or on silica gel at room temperature until DNA extraction.

\section{DNA extraction and gene amplification}

Total genomic DNA was extracted from each specimen using the DNeasy tissue kit (Qiagen, CA, USA). Polymerase chain reaction was used to amplify a 1200 base pair (bp) fragment of the mtDNA COI gene using the primers UEA3 and UEA10 described in [41]. The white gene was also amplified via PCR using the primers WF and W2R [42,43]. The amplification of the ITS2 was performed following the protocol described in [44] with 


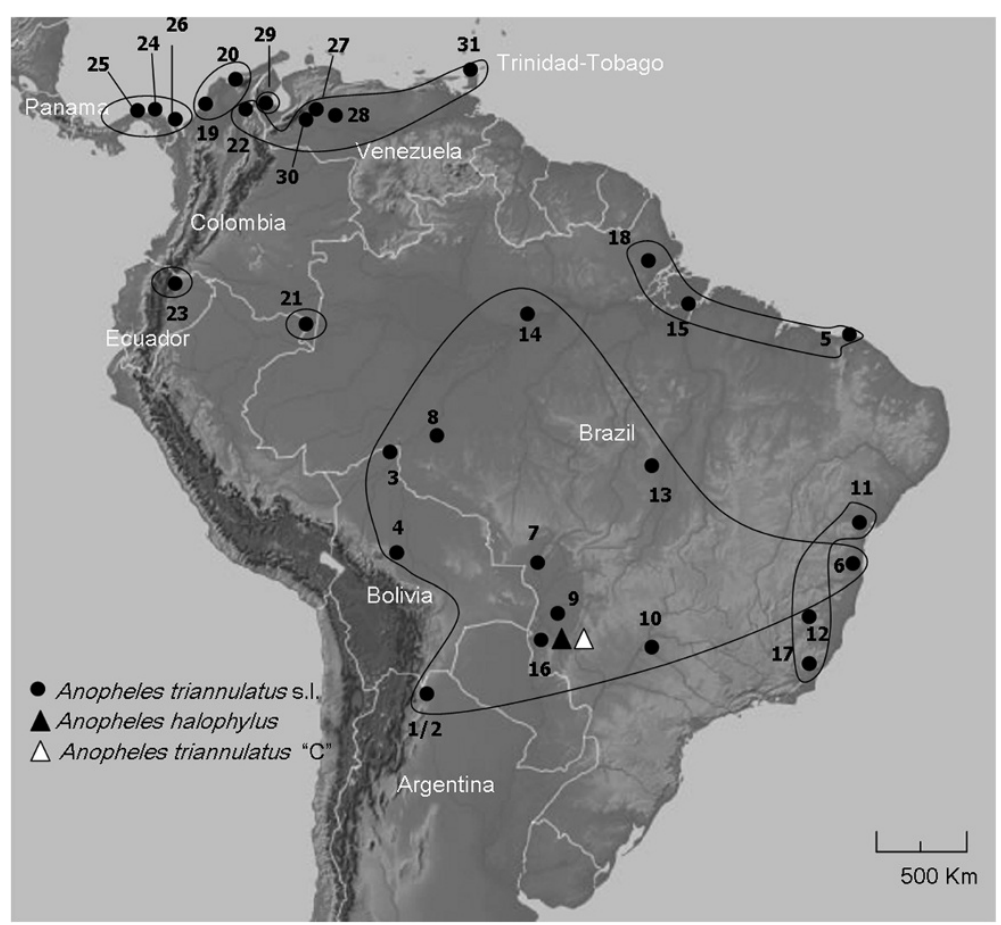

Figure 1 Anopheles triannulatus s.l. sampled localities. The locality numbers correspond to those in Table 1. Black dots represent Anopheles triannulatus s.l., black and white triangles represent An. halophylus and An. triannulatus C type localities, respectively. The map depicts the $k=9$ groups yielded by SAMOVA software and supported by AMOVA analysis.

the primers $5.8 \mathrm{~S}$ and 28S, yielding a 500 bp fragment. Each PCR reaction was carried out using a Ready-ToGo-PCR bead (Amersham Pharmacia/Biotech NJ, USA) and performed in a PTC-200 thermal cycler (BioRad Inc.). PCR products were purified on CentriSpin 40 columns (Princeton Separations, NJ, USA). Following standard PCR reactions, both strands were sequenced at the Applied Genomic Technologies Core (Wadsworth Center) on an ABI PRISM 3700 automated DNA sequencer.

\section{Sequence alignment and phylogenetic analysis}

Sequencer 4.1 (Gene Codes Corps.) was used for automatic sequence alignment into contigs and proofreading sequences files; subsequently, all sequences were aligned with Clustal W and then compiled in Bioedit 4.0 [45].

The data sets defined for the subsequent analyses were: 1) the $C O I$ fragment, 2) the COI gene with nt $1+n t 2$ positions (to avoid redundancy in the nt3 position), 3) the white gene (with and without intron), 4) the ITS2 and 5) a combined concatenated data set of the three fragments. For each data set, an appropriate model of nucleotide substitutions was obtained with the software jModeltest 3.5 [46]. The models obtained were GTR $+\mathrm{I}+\mathrm{G}$ for the $\mathrm{COI}$ gene (all positions), K81uf $+\mathrm{I}+\mathrm{G}$ for $\mathrm{COI}$ gene (nt1 + nt2 positions), GTR + G for the white gene and HKY for the ITS2, selected by using the Akaike Information Criterion
(AIC). These model parameters were used as prior information in the subsequent maximum likelihood (ML) and Bayesian analyses.

To reconstruct phylogenetic relationships, four different approaches with each of the data sets were conducted. The ML analyses were performed using the heuristic search algorithm; both analyses were performed on the haplotypes with branch support evaluated by 1000 bootstrap replicates.

Bayesian inference (BI) analysis was performed using MrBayes 3.0.4 [47] allowing, in the combined data set, the specification of a distinct model and parameters for the subset [48]. Different partitioning strategies were defined: P1) is a partition for each gene; P2) a partition for each gene without the $3^{\text {rd }}$ codon position for the mitochondrial marker and P3) the combined sequence without partitions. A Bayes factor $\left(2 \ln B_{\mathrm{F}}\right)$ was used to choose the best partitioning strategies. Analyses were initiated with random starting trees and run for $10,000,000$ to $20,000,000$ generations, sampling every 1000 generations with a 'burnin' of $25 \%$. Posterior probabilities were used to assess nodal support. FigTree v1.2.1 was employed for visualization of the consensus trees.

\section{Population structure and genetic diversity analysis}

Nucleotide and haplotype diversities were calculated within the main mitochondrial lineages, defined by the 
previous $\mathrm{BI}$ and the minimum spanning network, using DNASP v 5 [49].

A spatial analysis of molecular variance (SAMOVA) was performed to define groups of populations as geographically homogeneous and with a maximum of differentiation from each other, combining genetic and geographic sample information [50]. The random partition of the data was run by defining $K=2-20$, with $K$ number of groups to maximize the $F_{\mathrm{CT}}$ index, i.e., the proportion of total genetic variance due to differences between groups of populations [51].

In addition, the characterization of patterns of genetic diversity variation in the Anopheles triannulatus Complex was performed with the analysis of molecular variance (AMOVA), with the option of establishing different hierarchical levels [51]. Groups of variation were defined based on SAMOVA, BI and networks (Figure 2): 1) 9 groups obtained from SAMOVA; 2) SAMOVA groups but with Ecuador (23; Figure 1) and Amazonian Colombia (21; Figure 1) together; 3) SAMOVA groups but combining Venezuela (29) with those from western Colombia $(19,20)$; and 4) SAMOVA groups but combining locality 29 with the Venezuelan and Trinidad-Tobago populations.

To describe patterns of population genetic variation that originated from spatially limited gene flow, isolation by distance (IBD) was tested with a nonparametric Mantel test through the web-based computer program IBDWS v3.16 [52]. This analysis was applied only to populations in northwestern Latin America for which we have adequate regional (geographical) sampling. In this case, the distance was calculated as the straight line geographical distance between pairs of sampled localities using the Geographic Distance Matrix Generator tool [53] and the validation of the analysis was provided by 10,000 randomizations. Partial Mantel tests were performed to test for the effect of the Andes on genetic divergence [54].

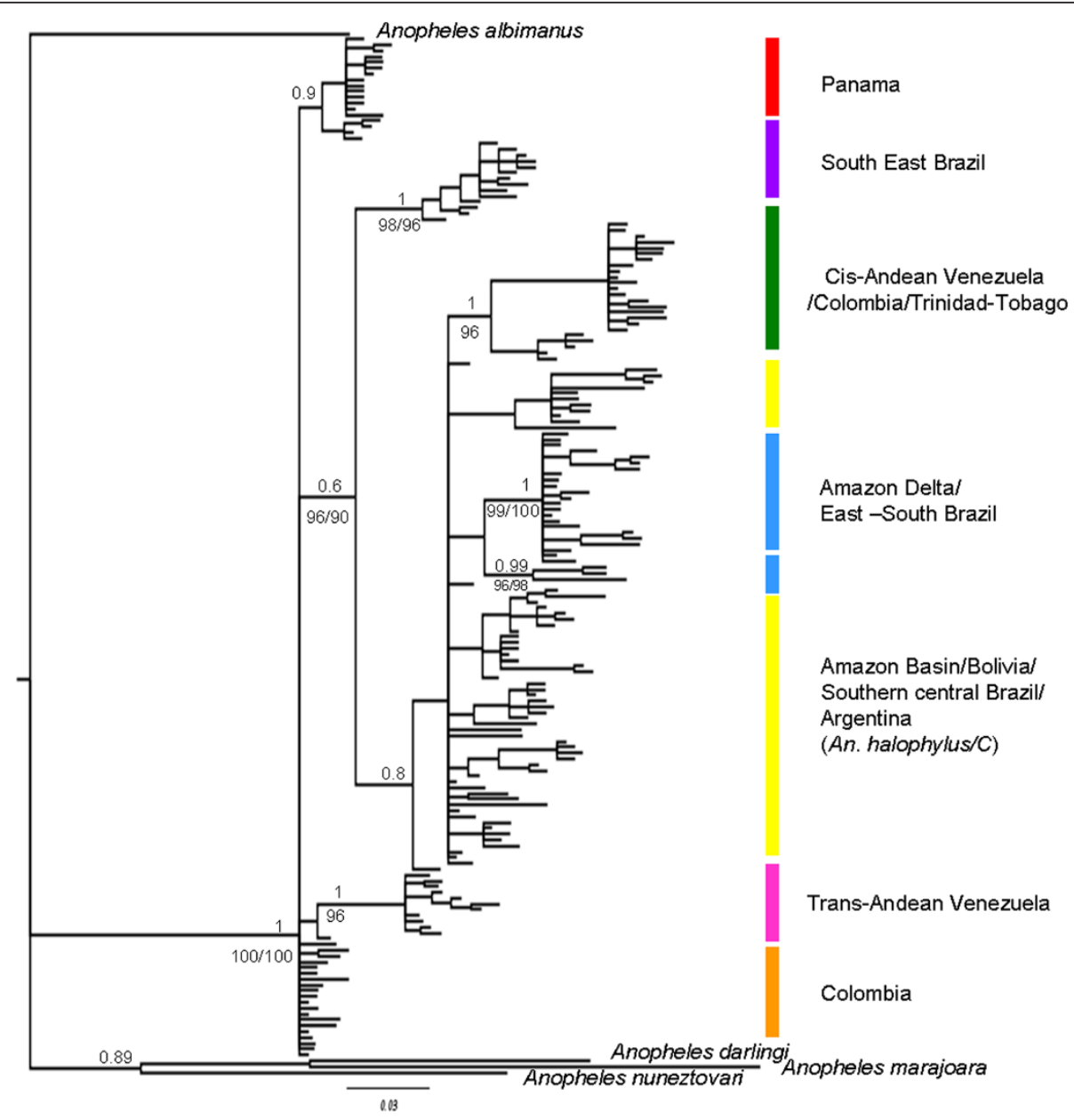

Figure 2 Tree topology MP, ML and BI of the mitochondrial COI gene of the Anopheles triannulatus complex. Both procedures produced trees of similar topology, with only branch support values above 70\% shown. Bayesian posterior probability is above the branch and Maximum Likelihood bootstrapping (percentage) is below the branch. Anopheles albimanus, Anopheles darlingi, Anopheles nuneztovari and Anopheles marajoara were used to root the tree. 


\section{Phylogeographic analysis}

To infer the haplotype relationships within the data sets, the median-joining network algorithm was performed [55], available in NETWORK v 4.5.1.0 (www.fluxus-engineering. com), which combines the topology of a minimum spanning tree with a parsimonious search for the missing haplotypes. To determine the ancestral network node, COI sequences of closely related species, Anopheles nuneztovari and Anopheles darlingi were included. Because this algorithm was designed for non-recombining molecules, a statistical parsimony network was used for the nuclear white gene and the ITS2 data [56] with a 95\% confidence level, using the TCS v 1.21 software [57].

\section{Inference of population history}

To investigate the historical demography of the Anopheles triannulatus Complex, neutrality tests were performed and applied to the SAMOVA groups and to the entire data set. The first two estimates (Tajima's $D$ and $R_{2}$ ) are based on the frequency spectrum of mutation whereas Fu's Fs is based on linkage disequilibrium and haplotype distribution. To further confirm demographic expansion events, mismatch distribution analyses were conducted. The time of expansion was estimated using the formula $\tau=2 u t_{\mathrm{e}}$, where $\tau$ is estimated in the mismatch distribution analysis, $u$ is the nucleotide mutation rate in the specific DNA region and $t_{\mathrm{e}}$ is time since expansion. The mutation rate in the mitochondrial gene has been estimated from Drosophila as $1 \times 10^{-8} /$ site/year [58]. The time of the beginning of lineage divergence was calculated following $D_{\mathrm{A}} / 2 k$, where $D_{\mathrm{A}}$ is the average nucleotide divergence between lineages and $2 k$ is the divergence rate [59]. We utilized the COI gene substitution rate of $2.3 \%$ divergence per million years [60] and estimated these parameters and their significance based on the coalescence process in DNASP v 5.10 [49] and Arlequin v3.11 [61].

\section{Results}

A total of 326 specimens of the Anopheles triannulatus complex were sequenced for the mtDNA COI gene (Table 1). All sequences could be unambiguously aligned and no insertions or deletions were found. Translation into amino acid ruled out the presence of nuclear mitochondrial pseudogenes.

The final alignment of the COI gene (partial sequence) had a length of $689 \mathrm{bp}$, of which 202 characters were variable polymorphic sites and 154 were parsimony informative. For the single-copy nuclear white gene, 85 individuals randomly selected were included, representing each of the mtDNA-based lineages, and the An. halophylus and $A n$. triannulatus $\mathrm{C}$ samples. A fragment of $646 \mathrm{bp}$ with an intron of 70 bp was detected within the white gene sequences in all individuals, independent of the species. This intron was excluded for some of the analyses using a final fragment of $576 \mathrm{bp}$.

Finally, ITS2 was amplified from 34 individuals randomly chosen from the COI lineages, and the length varied from 542-570 bp (intra and interspecific differences), with a final alignment length of 483 bp (3' and 5' ends to make sequences equal length). All sequences were deposited in GenBank under Accession numbers COI (JN085964JN086138), white gene (JF931140-JF931172) and ITS2 (JF972999-JF973009).

\section{Phylogenetic analysis \\ Mitochondrial DNA data}

The Bayesian, ML and MP trees of the overall analysis are shown in Figure 2. Trees were rooted using Neotropical Nyssorhynchus species: Anopheles darlingi, Anopheles marajoara, Anopheles nuneztovari and Anopheles albimanus as outgroup [62]. The tree topologies obtained by the $50 \%$ majority rule consensus using BI, ML and MP in PAUP were basically in agreement, consistently recovering the Anopheles triannulatus complex as a monophyletic lineage. Two main clades were identified based on the geographic distribution of the samples (with some exceptions) and their genetic distances: one encompassing samples from Panama, northern Colombia and trans-Andean Venezuela, and the other (Amazonian) including samples from South America and cis-Andean Venezuela, and An. halophylus and An. triannulatus C. Within the Amazonian clade further subclades can be described according to tree topology and geographic origin of the samples (Figure 2). Both topologies suggest that the clade, which encompasses samples from Colombia is the most basal within the Complex. The main differences in the tree topologies were the recovery of Panama, Colombia and trans-Venezuela (northern) as a unique clade, although with low posterior probability branch support. The second clade (Figure 2) is shallower when estimated by MP, and not all the subclades are supported.

The samples identified as An. halophylus and $A n$. triannulatus $\mathrm{C}$ were in a clade together with other individuals identified as An. triannulatus s.s. from southern Brazil, Bolivia and Argentina. In all tree topologies, An. halophylus shares the same haplotype as one individual from eastern Brazil originally identified morphologically and by $M p i$ as An. triannulatus s.s.

Analysis excluding the nt 3 codon position was performed because of saturation issues [63], but this did not improve the resolution of the topologies. No evidence for saturation at any of the 3 positions was found using the test in [64] (Additional file 1).

\section{Nuclear DNA data}

A total of 33 haplotypes were identified among 85 individuals sequenced for the white gene. Bayesian tree (Figure 3) was similar to the three generated, employing 
MP analyses topology resolved a similar phylogeny, with some of the clades associated to geographic distribution. For instance, one major node includes individuals from central and northwestern South America and another includes samples from eastern and central Brazil (localities 5, 10, 13, Figure 1). In contrast, other individuals have low support or no geographic concordance, such as the genotypes from localities 4, 17 and 28. An. halophylus and An. triannulatus C clustered together with high support with two other $A n$. triannulatus s.l. specimens from localities 1 and 7 .

All 33 unique white gene genotypes could be connected (Figure 4A). Genotype 1, with individuals from Panama, Colombia and Venezuela, was identified as ancestral [65]: the internal position in the network, the number of lineages that arise from it and the frequency (24 samples). The second most common genotype (number 6) is separated by only 3 mutational steps from genotype 1, and contains 9 samples from NE Brazil. Many of the remaining genotypes were unique $(n=23)$ and only eight were shared. The minimum spanning network depicted a complex pattern of relationships among the genotypes, and there was no support for the BI groups (Figure 2) in the mitochondrial or the nuclear gene genealogy.

Bayesian inference, maximum parsimony and maximum likelihood analysis of the ITS2 marker yielded similar topologies with only subtle differences in bootstrap and posterior probability support values (data not shown).
The tree topologies showed some possibly basal individuals from diverse localities (Colombia, Panama, Brazil, and Venezuela) and two fairly well supported subclades: one of them recovers $A n$. halophylus and $A n$. triannulatus $C$ as a single monophyletic clade. The other clade contains individuals from central Brazil, southern Colombia, Ecuador and Bolivia. In addition, the ITS2 network (Figure 4B) clearly depicts 3 main groups in the Anopheles triannulatus Complex; lineage I recovered individuals from Panama, trans-Andean Venezuela, NE Brazil and SE Brazil whereas lineage II comprised Amazon Basin and trans-Andean Venezuela individuals. Lineage III consisted of two genotypes separated by 1 mutation step with the $A n$. halophylus and An. triannulatus $C$ specimens, plus two individuals from Brazil and Argentina (originally identified as An. triannulatus s.l.), respectively. The deep differentiation of populations separated by the Andes, detected by the COI data, is also strongly supported with ITS2 lineages I and II.

\section{Combined mitochondrial and nuclear DNA data}

Analysis of partitioning strategies showed the P1 model (independent evolutionary models for each gene) as the most accurate [66]. $B_{F}$-based statistics also indicated this partition as the better fit, and the tree derived from these analyses is shown in Figure 5. In general, the combined data presented high posterior probability values. The tree topology recovered two main clades; clade

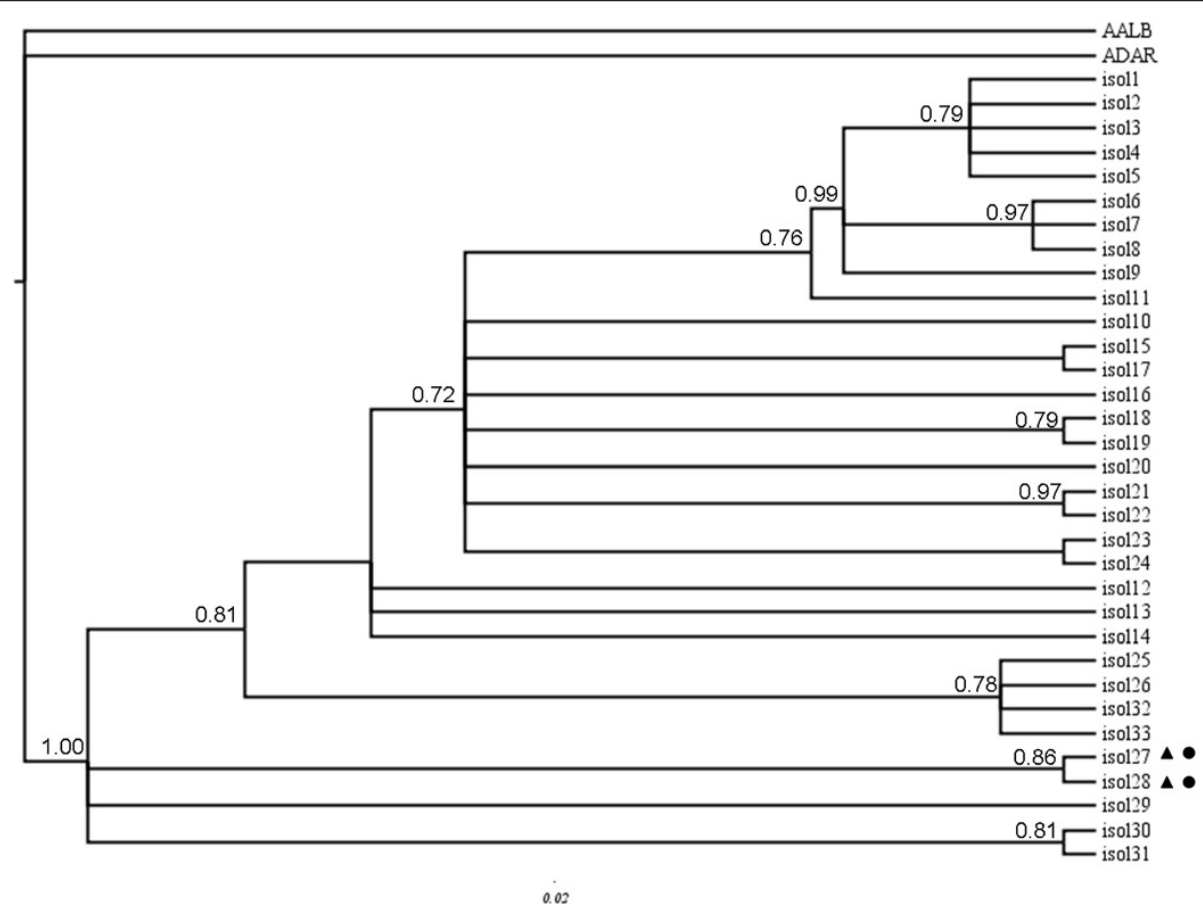

Figure 3 Bayesian phylogenetic tree based on the white gene of the Anopheles triannulatus complex. Black circles represent An. triannulatus $C$ and black triangles An. halophylus. Anopheles albimanus (AALB) and Anopheles darlingi (ADAR) were used to root the tree. 


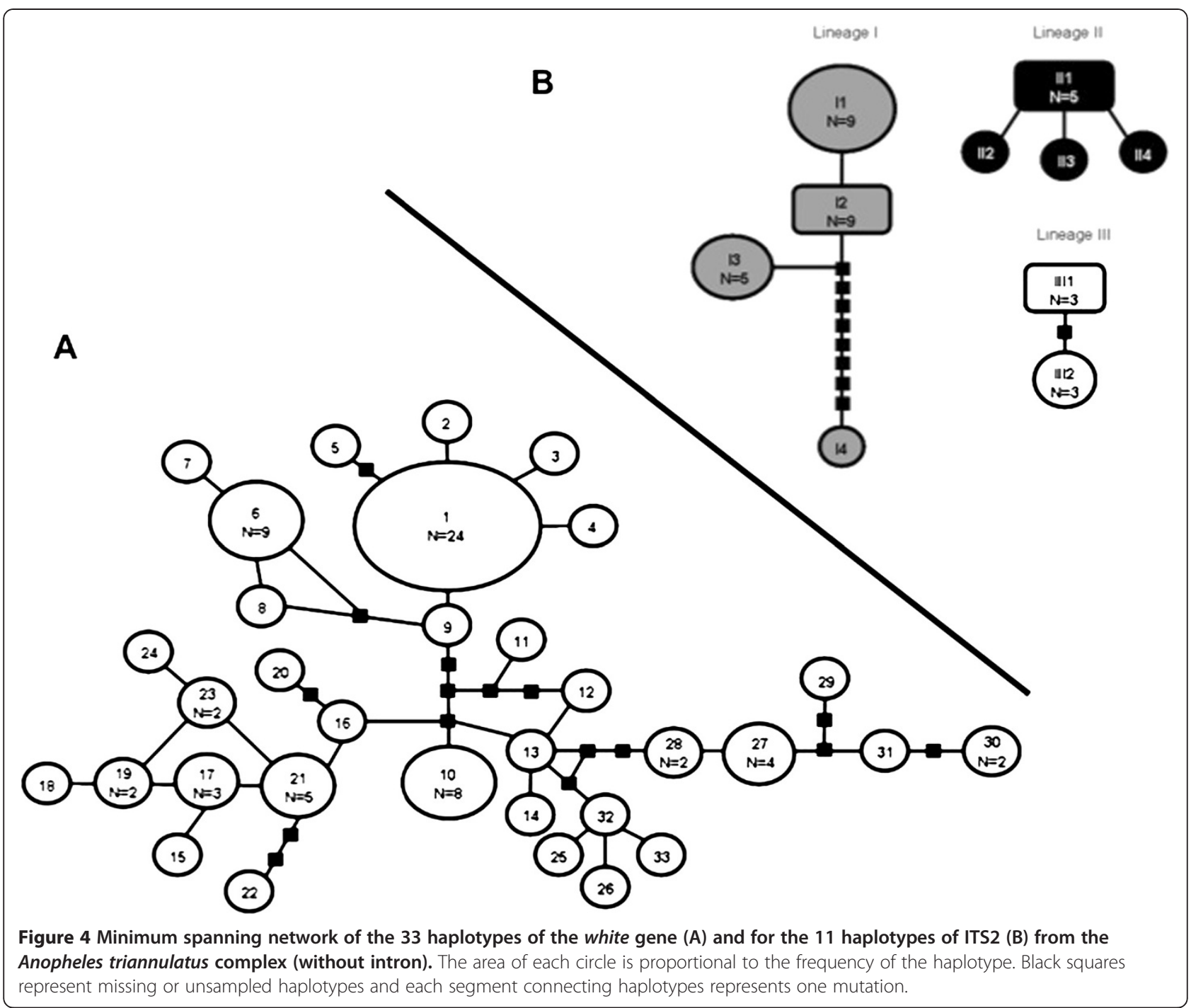

I consists of multiple subclades: (1) An. halophylus $+A n$. triannulatus C; (2) trans-Andean Venezuela; (3) central Amazonia + central Bolivia; (4) Atlantic coastal forest; and (5) Amazon delta. Clade II includes three subclades: (1) Panama; (2) cis-Andean Colombia; and cis-Venezuela. The Amazon delta specimens are in both clades (OC9, OC7 in Clade I and OC14 in Clade II), perhaps indicating sympatry of discrete taxa. Anopheles halophylus and An. triannulatus $\mathrm{C}$ were recovered as a single well-supported monophyletic subclade (1) together with some An. triannulatus s.l. individuals from the same type locality (Salobra) and from nearby Mato Grosso and Argentina. The other subclades (2-5) generally had a geographic component except that samples from Bolivia are found in both subclades 2 (PV9) and 3 (PV5) (Figure 5).

\section{Population structure and genetic diversity analysis}

The 326 sequences of the COI gene yielded one hundred and seventy-five haplotypes, with some shared between species, for instance, for $A n$. triannulatus $\mathrm{C}$ and $A n$. triannulatus s.s (see Table 2). The haplotype network reveals an intricate topology (Figure 6): from Panama, haplotypes A4 $(n=12)$ and A9 $(n=16)$, were the most common; C6 (Venezuela and Brazil) and D12 (NE Brazil) each comprised 11 individuals, whereas F11 (NW Colombia) consisted of 15 individuals. An. halophylus (E8 and E53) present haplotypes intermingled with An. triannulatus s.s. from eastern Brazil and Mato Grosso. Conversely, both An. triannulatus C haplotypes (E7 and E9) were unique.

Overall, the Anopheles triannulatus complex network consists of 7 lineages, very similar to the BI, and depicts some relationships between haplotypes and geographic distribution, which may indicate variation in the population histories (Figure 6). Star shaped lineage A, suggestive of population expansion, is restricted to Panama. Other geographically nearby lineages, separated only by 2 mutational steps, are formed by trans-Andean Colombian (F); but 


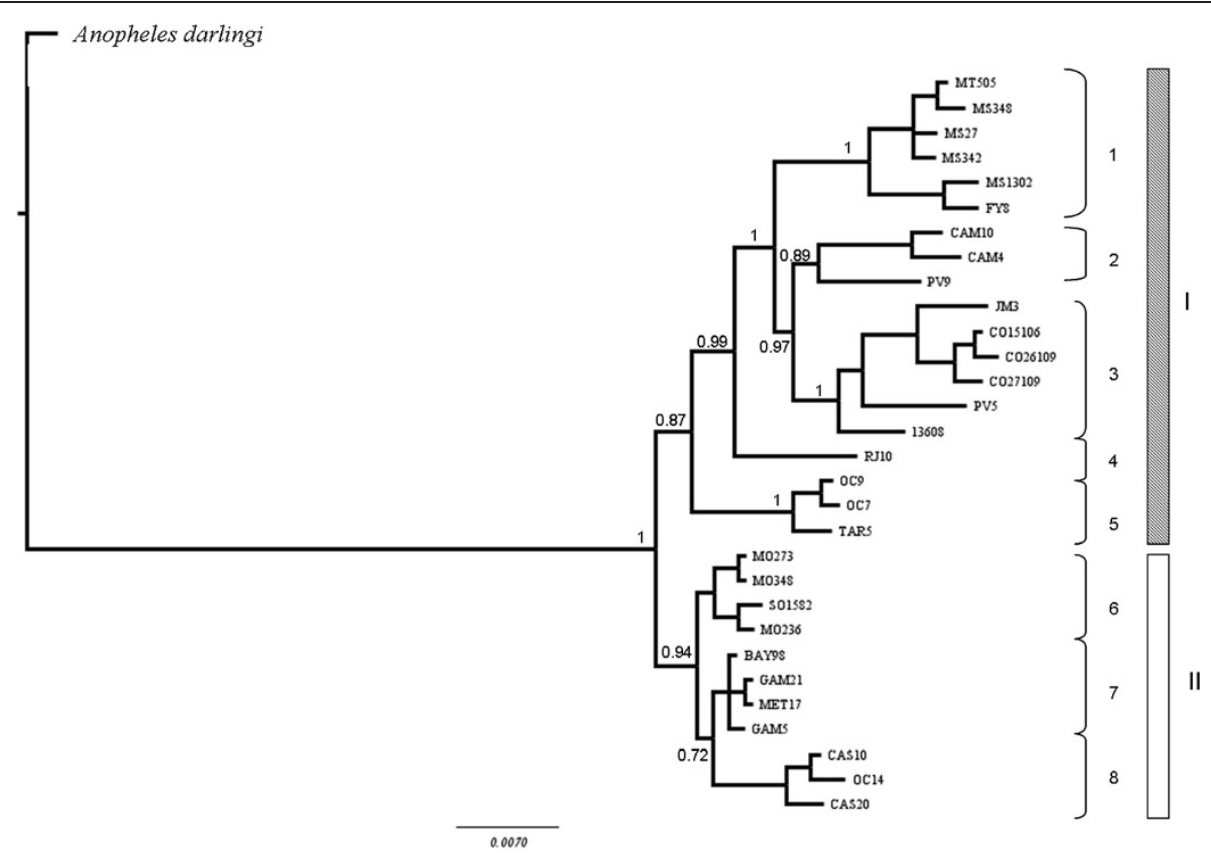

Figure 5 Bayesian analysis of the concatenated $\mathrm{COI}+$ white gene + ITS2 alignment. Support values for common branches are represented above branches estimated using a partition for each gene: $G T R+I+G$ for the COl gene (all positions), GTR $+G$ for the white gene and HKY for the ITS2 model of evolution. The outgroup Anopheles darlingi was used to root the tree.

there are $>11$ mutation steps between $\mathrm{A}$ and the western Venezuelan samples $(C)$. In contrast, lineage $B$, consisting of haplotypes from cis-Andean Venezuela, Colombia, and Trinidad and Tobago, is $>21$ mutational steps distant. Lineage $\mathrm{E}$ is of mixed origin: samples from Ecuador, Bolivia, Amazonian Colombia, southern Brazil, Argentina and a few haplotypes from central and eastern Brazil, mostly as singletons. Lineage D is mainly composed of eastern Brazilian populations with a star shape suggesting an expansion. Lineage $\mathrm{G}$ is restricted to populations from SE Brazil, east of the Central Mountain Range.

The SAMOVA $F_{\mathrm{CT}}$ values increased with the number of groups. However, the graphical representation of $F_{\mathrm{CT}}$ showed that at $k=9$, a plateau was reached $\left(F_{\mathrm{CT}}=0.53778\right)$ concordant with the most statistically significant AMOVA groups (Table 3).

A Mantel test showed a significant correlation of pairwise genetic differences between the Panamanian, Colombian and Venezuelan samples with their respective geographic distances $(r=0.6564, p<0.001)$, suggesting that distance accounts for approximately $65 \%$ of the genetic differentiation for this region. Furthermore, a partial Mantel test was performed to test the Andes as a barrier to gene flow between mosquito populations from Panama (trans) and Colombia and Venezuela (cis). In this case, the distance still added significant effect to the correlation when the Andean range was primarily considered $(r=0.6463 ; p<0.01)$ (controlling for geography: $r=-0.0115 ; p=0.5860)$.

\section{Inference of $\mathrm{COI}$ population history}

All the neutrality tests in lineage A were significant, strongly indicating a demographic expansion (Table 4). All the other lineages presented significant $F s$ and $R_{2}$ statistics. In addition, the unimodal mismatch distribution and the nonsignificant raggedness statistics are congruent with a model of sudden expansion in all lineages (Figure 7). A range of early to late Pleistocene divergence was identified in all the lineages, with the oldest estimation for widespread lineage E. However, visually, lineage $\mathrm{E}$ mismatch distribution and the haplotype network are more consistent with an older lineage close to equilibrium. Interestingly, if we combined Venezuelan lineages ( $B$ and $C$, excluding the single D1 haplotype), they depicted two different peaks in the mismatch distribution, corresponding to cis- and transAndean populations (395,821-327,737 years ago, respectively). The IBD test may be showing positive correlation with the distance as an artifact, because of the demographic expansion of the populations included in the analysis.

A McDonald-Kreitman (MK) test was performed for each lineage to detect departures from neutral theory at the molecular level. There was no evidence of selection on either COI or white genes in several locations tested, using different species of Anopheles as outgroups.

\section{Discussion}

Taxonomic status of the Anopheles triannulatus complex

This study assesed the phylogenetic relationship of the An. triannulatus complex based on mitochondrial and 
Table 2 Description of shared COI haplotypes for the An. triannulatus complex

\begin{tabular}{|c|c|c|c|c|c|}
\hline Site no. & Country & Locality & $N$ & Haplotypes & Lineages \\
\hline 1 & Argentina & Yuto Farm (FY) & 23 & $\begin{array}{c}\mathrm{E} 1, \mathrm{E} 2, \mathrm{E} 4, \mathrm{E} 15, \mathrm{E} 44(2), \mathrm{E} 45, \mathrm{E} 46, \mathrm{E} 47, \mathrm{E} 50(2), \mathrm{E} 51, \mathrm{E} 52, \\
\mathrm{E} 57, \mathrm{E} 66(3), \mathrm{E} 67(4), \mathrm{E} 68, \mathrm{E} 69\end{array}$ & $E$ \\
\hline 2 & & Lake Yuto (LY) & 3 & $\mathrm{E} 58, \mathrm{E} 67, \mathrm{E} 70$ & $\mathrm{E}$ \\
\hline 3 & Bolivia & Guayaramerin (GU) & 4 & E32(4) & $E$ \\
\hline 4 & & Puerto Villaroel (PV) & 10 & $\mathrm{E3}, \mathrm{E} 5, \mathrm{E} 6, \mathrm{E} 12(2), \mathrm{E} 13, \mathrm{E} 49, \mathrm{E} 62, \mathrm{E} 63(2)$ & $\mathrm{E}$ \\
\hline 5 & Brazil & Ceara (CE) & 2 & D21,D22 & $\mathrm{D}$ \\
\hline 6 & & Espirito Santo (ES) & 1 & E53 & $\mathrm{E}$ \\
\hline 7 & & Fazenda S. Joao (MT) & 2 & E61,E8 & $\mathrm{E}$ \\
\hline 8 & & Monte Negro (RO) & 5 & E22, E23,E59(2),E65 & $E$ \\
\hline 9 & & Aquidauana (Pantanal do Rio Negro) (AQU) & 6 & D23,E17,E18,E19,E20,E21 & $\mathrm{D}, \mathrm{E}$ \\
\hline 10 & & Inubia Paulista (SP) & 6 & E1,E28,E29,E30,E48,E58 & $\mathrm{E}$ \\
\hline 11 & & Camacan/Santa Luzia (Bahia) (BA) & 7 & $\mathrm{G} 3, \mathrm{G} 4, \mathrm{G} 5, \mathrm{G} 6, \mathrm{G} 7, \mathrm{G} 8, \mathrm{G} 9$ & G \\
\hline 12 & & Coronel Pacheco (Minas Gerais) (MG) & 6 & $\mathrm{G} 10, \mathrm{G} 11, \mathrm{G} 12, \mathrm{G} 13, \mathrm{G} 14, \mathrm{E} 31$ & $\mathrm{G}, \mathrm{E}$ \\
\hline 13 & & Lagoa da Confusao (Tocantins) (TO) & 6 & E24, E25, E26, E27,E56,E65 & $\mathrm{E}$ \\
\hline 14 & & Itaituba (ITB) & 5 & E16,E50,E56,E64,E65 & $\mathrm{E}$ \\
\hline 15 & & Oswaldo Cruz (OC) & 19 & D1,D5,D6,D7,D8,D12(7), D13(2),D14(2),D15, D16,C6 & $C, D$ \\
\hline 16 & & Salobra (MS) & 20 & 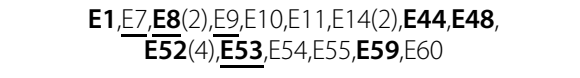 & $\mathrm{E}$ \\
\hline 17 & & Silva Jardim (RJ) & 2 & $\mathrm{G} 1, \mathrm{G} 2$ & G \\
\hline 18 & & Tartarugalzinho (TAR) & 23 & $\begin{array}{c}\mathrm{D} 2, \mathrm{D} 3, \mathrm{D} 4, \mathrm{D} 9, \mathrm{D} 10(4), \mathrm{D} 11, \mathrm{D} 12(4), \mathrm{D} 17, \mathrm{D} 18(4), \\
\mathrm{D} 19(2), \mathrm{D} 20, \mathrm{E} 43(2)\end{array}$ & $D, E$ \\
\hline 19 & Colombia & Monitos (MO) & 23 & $\begin{array}{c}\text { B3,F1,F2, F3, F4(2),F8,F9, } \\
\text { F11(9),F12(2),F13,F14,F16,F17 }\end{array}$ & $B, F$ \\
\hline 20 & & Santa Rosa de Lima (SO) & 27 & $\begin{array}{l}\mathrm{B} 18, \mathbf{F 1}, \mathbf{F 4}(6), \mathrm{F} 5(2), \mathrm{F} 6, \mathrm{~F} 7, \mathbf{F} 8, \mathbf{F 9} 9(3) \\
\quad \mathrm{F} 10, \mathrm{~F} 11(6), \mathrm{F} 15, \mathrm{~F} 18, \mathrm{~F} 19, \mathrm{~F} 20\end{array}$ & $B, F$ \\
\hline 21 & & Leticia, km12 (COSW) & 10 & E36,E37(4),E38,E39,E40,E41,E42 & $\mathrm{E}$ \\
\hline 22 & & Tibu (COL) & 3 & B14,B19,C11 & $B, C$ \\
\hline 23 & Ecuador & Juan Montalvo (JM) & 6 & E33(4), E34, E35 & $\mathrm{E}$ \\
\hline 24 & Panama & Bayano (BAY) & 7 & $\mathbf{A 3}, \mathbf{A 4}, \mathbf{A} \mathbf{9}, \mathrm{A} 14, \mathbf{A} 1 \mathbf{6}(2), \mathrm{A} 18$ & A \\
\hline 25 & & Gamboa (GAM) & 29 & $\begin{array}{c}\mathrm{A} 1, \mathrm{~A} 2, \mathbf{A} \mathbf{3}, \mathbf{A} 4(3), \mathrm{A} 5, \mathrm{~A} 6, \mathrm{~A} 7, \mathrm{~A} 8, \mathbf{A} \mathbf{9}(10), \mathrm{A} 10(4) \\
\mathrm{A} 11, \mathrm{~A} 12, \mathrm{~A} 13, \mathbf{A} 16, \mathrm{~A} 17\end{array}$ & A \\
\hline 26 & & Meteti (MET) & 17 & $\mathbf{A 4}(8), \mathbf{A} \mathbf{9}(5), \mathrm{A} 14, \mathrm{~A} 15, \mathbf{A} \mathbf{1 6}(2), \mathrm{A} 19$ & A \\
\hline 27 & Venezuela & Boconoito (BOC) & 6 & $\mathrm{~B} 1, \mathbf{B 2}, \mathbf{B 3}, \mathrm{B} 8(2), \mathbf{B 9}$ & B \\
\hline 28 & & Cano Amarillo (CAM) & 15 & B2,B3, B4, B5, B9,B10(2), B11, B12(2), B13, B14(4) & B \\
\hline 29 & & Casigua Zulia (CAS) & 25 & $\mathrm{D} 1, \mathrm{C} 1(4), \mathrm{C} 2, \mathrm{C} 3(2), \mathrm{C} 4, \mathrm{C} 5, \mathrm{C} 6(10), \mathrm{C7}, \mathrm{C} 8, \mathrm{C} 9(2), \mathrm{C} 10$ & $D, C$ \\
\hline 30 & & La Veguita (VG) & 6 & $\mathrm{~B} 6, \mathrm{B7}, \mathrm{B} 15, \mathrm{~B} 16, \mathrm{~B} 17, \mathrm{~B} 18$ & B \\
\hline 31 & Trinidad-Tobago & St.Andrew/St.David, Valencia (TRI) & 2 & B7 (2) & B \\
\hline
\end{tabular}

The number in parentheses indicates the frequency of the haplotype at that site; bold numbers are shared haplotypes, plain numbers are unique haplotypes in that population and underlined numbers are An. halophylus (E8, E53) and An. triannulatus C (E7, E9).

nuclear data. Results of phylogenetic analysis showed that An. halophylus and An. triannulatus $\mathrm{C}$ do not form separate monophyletic clades, indicating that they are probably very closely related or are incipient species as proposed by Silva-do-Nascimento and collaborators $[20,21]$. The COI uncorrected pairwise genetic distances detected a $0.2 \%$ divergence between these putative taxa, whereas with those identified as An. triannulatus s.s. the range varied from $1.7-2.3 \%$, depending on the sample. Therefore, this study supports the conclusion that $A n$. halophylus and An. triannulatus $\mathrm{C}$ are more closely related to each other than either is to An. triannulatus s.s. $[20,21]$. Furthermore, the combined three gene analysis recovered a highly supported single clade consisting of 


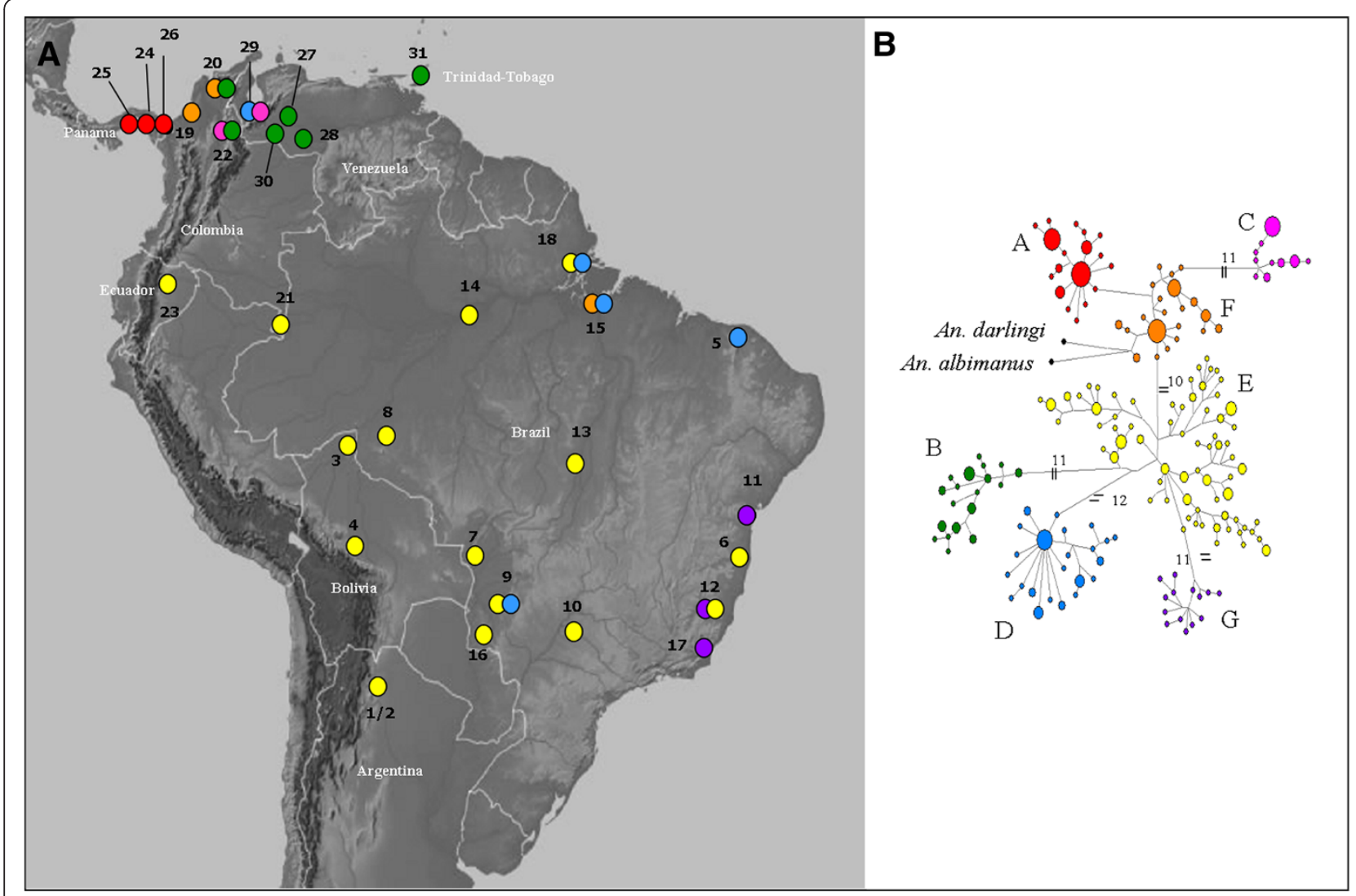

Figure 6 Haplotype network derived from 175 haplotypes from $689 \mathrm{bp}$ of the COI gene sequences from 326 specimens of the Anopheles triannulatus complex. A) Geographic distribution of the COl lineages; B) Haplotypes are represented by circles and their frequency is proportional to the area. Numbers represent mutational steps between haplotypes and grey dots are median vectors. The An. darlingi and An. nuneztovari outgroup sequences (black dots) joined the network at the Colombian haplotypes and they are separated from all the Anopheles triannulatus complex individuals by more than 50 fixed differences.

An. halophylus and An. triannulatus C, whereas the mitochondrial COI gene provided a tree with lower resolution (short branches, low support) for the three species.

Diverse processes in the mitochondrial marker such as introgression or incomplete lineage sorting may be responsible for the inconclusive phylogenetic analysis within the complex. In addition, representatives from Argentina and Mato Grosso (Brazil) were recovered in every tree topology clustered together with An. halophylus and An. triannulatus $\mathrm{C}$, and may represent a more extensive distribution of this taxa. Actually, specimens morphologically similar to $A n$. halophylus and An. triannulatus $\mathrm{C}$ were reported in Western Brazilian Amazon, Paraguay and Bolivia [15,19,22,29,67].

Evidence of shared haplotypes, i.e. between $A n$. halophylus and An. triannulatus s.s. and between $A n$. triannulatus s.s. and $A n$. triannulatus $C$ were also found with this gene. The presence or absence of the intron in the white gene is an evolutionary event that appears more than once in the history of anophelines [68,69]. Within the An. triannulatus complex, all three species retained this intron and there were no significant nucleotide differences among their sequences.

The divergence of ITS2 lineages was very low within $(0.2 \%$ in lineage I and II and 0 in lineage III) and between lineages $(0.7 \%$ between I and II; $1 \%$ and $1.1 \%$ between I and III and II and III, respectively). Therefore, the ITS2 findings alone did not conclusively differentiate An. halophylus and An. triannulatus C, which suggest that a low level of gene flow may occur or have taken place in the recent past, as it has been proposed when analyzing sympatric specimens from Brazil with sequences of timeless gene alone [21]. On the other hand, the analysis of cpr gene sequences of the same specimens revealed fixed differences and considerable genetic differentiation between An. halophylus and An. triannulatus C [21].

The phylogenetic reconstruction supports monophyly of the An. triannulatus complex. The three genes detected different phylogenetic relationships as well as phylogeographic patterns in this complex. Nuclear DNA markers are expected to provide older demographic 
Table 3 Analysis of Molecular Variance (AMOVA) using COI in the An. triannulatus complex

\begin{tabular}{|c|c|c|c|}
\hline Groups (localities) & Among groups & Among populations within groups & Within populations \\
\hline 1) & 53.81 & 3.24 & 42.95 \\
\hline I: $24,25,26$ & $\Phi_{C T}=0.53^{* * *}$ & $\Phi_{\text {ST }}=0.57^{* * *}$ & $\Phi_{S C}=0.07^{* * *}$ \\
\hline \multicolumn{4}{|l|}{ II: 19,20} \\
\hline \multicolumn{4}{|l|}{ III; 5, 15, 18} \\
\hline \multicolumn{4}{|l|}{ IV: 29} \\
\hline \multicolumn{4}{|l|}{ V: $22,27,28,30,31$} \\
\hline \multicolumn{4}{|l|}{ VI: 23} \\
\hline \multicolumn{4}{|l|}{ VII: $11,12,17$} \\
\hline \multicolumn{4}{|l|}{ VIII: 21} \\
\hline \multicolumn{4}{|l|}{ IX: $1,2,3,4,6,7,8,9,10,13,14,16$} \\
\hline 2) & 53.13 & 3.90 & 42.96 \\
\hline VI: 21,23 & $\Phi_{C T}=0.531^{* * *}$ & $\Phi_{\mathrm{ST}}=0.57^{* * *}$ & $\Phi_{S C}=0.08^{* * *}$ \\
\hline 3) & 47.11 & 10.45 & 42.44 \\
\hline II: $19,20,29$ & $\Phi_{C T}=0.47^{* * *}$ & $\Phi_{\text {ST }}=0.57^{* * *}$ & $\Phi_{S C}=0.19^{* * *}$ \\
\hline 4) & 37.49 & 19.18 & 43.33 \\
\hline IV: $22,27,28,29,30,31$ & $\Phi_{C T}=0.37^{* * *}$ & $\Phi_{\text {ST }}=0.56^{* * *}$ & $\Phi_{S C}=0.3^{* * *}$ \\
\hline
\end{tabular}

1) Groups (localities number) derived from SAMOVA $k=9 ; 2$ ), 3) and 4) with modifications in the groups based on SAMOVA results. *** $p<0.001$.

information than mtDNA because dissimilar effective population size can affect estimations of coalescent time [70]. Therefore, the genetic relationships that we obtained with the white gene support an original metapopulation, across the entire known geographic distribution, with posterior divergence in some populations, reflected in the results of the COI gene. The mitochondrial loci in most species have a shorter expected coalescence time compared with nuclear loci (only one-fourth of the effective population size), and thus there is a greater probability that the mitochondrial gene tree will accurately reflect the species tree [71].

On the other hand, the ITS2 marker did not show different lengths between putative species, but see [44]. The characteristic mutation replacement of this locus (elevated number of indels and low frequency of replacement mutations) may be more useful for species-specific PCR diagnostics in species complex members [72,73] than for phylogenetic inference.

The COI fragment was useful to describe the genetic structure of the An. triannulatus complex. However, the genetic variation and divergence within and between lineages might reach a different conclusion if this study had been based on the more conservative "Folmer region" (DNA barcode standard) [74].

\section{Divergence and demographic expansion of the Anopheles triannulatus complex}

Anopheles triannulatus s.l. contains cryptic and geographically distinct mtDNA lineages, indicative of either

Table 4 Molecular diversity and neutrality test in the main mt-DNA lineages within the Anopheles triannulatus complex

\begin{tabular}{|c|c|c|c|c|c|c|c|c|c|c|}
\hline $\mathrm{COI}$ gene lineage & $N$ & $h$ & $\pi$ & $H d(\mathrm{SD})$ & $k$ & Fs & $F^{*}$ & $D^{*}$ & $D_{T}$ & $R^{2}$ \\
\hline A & 53 & 18 & 0.00275 & $0.841(0.035)$ & 1.894 & $-11.706^{* * *}$ & $-3.223^{* *}$ & $-3.205^{*}$ & $-1.802^{*}$ & $0.162^{* * *}$ \\
\hline B & 33 & 19 & 0.00776 & $0.960(0.018)$ & 5.348 & $-8.354^{* *}$ & -1.492 & -1.29 & -1.21 & $0.160^{* * *}$ \\
\hline C & 26 & 11 & 0.00457 & $0.806(0.071)$ & 3.148 & -2.558 & 0.106 & -0.0009 & 0.305 & $0.126^{* * *}$ \\
\hline D & 43 & 23 & 0.00628 & $0.921(0.030)$ & 4.328 & $-11.479^{* * *}$ & -1.373 & -0.981 & -1.483 & $0.109 * * *$ \\
\hline$E$ & 109 & 70 & 0.0194 & $0.989(0.003)$ & 13.383 & $-41.832^{* * *}$ & -1.972 & -1.999 & -1.173 & $0.090^{* * *}$ \\
\hline $\mathrm{F}$ & 48 & 20 & 0.00760 & $0.906(0.029)$ & 5.238 & $-6.361^{*}$ & $-2.775^{*}$ & $-2.748^{*}$ & -1.575 & $0.109^{* * *}$ \\
\hline G & 14 & 14 & 0.00636 & $1(0.027)$ & 4.385 & $-11.622^{* * *}$ & -1.588 & -1.429 & -1.265 & $0.151^{* * *}$ \\
\hline All & 326 & 175 & 0.0242 & $0.989(0.0017)$ & 16.676 & $-158.48^{* * *}$ & -1.924 & $-2.334^{*}$ & -0.914 & $0.075^{* * *}$ \\
\hline
\end{tabular}

A: Panama; B: cis-Andean Venezuela + Colombia + Trinidad-Tobago; C: Venezuela; D: NE and C Brazil + Venezuela; E: Ecuador, Colombia, Bolivia, Argentina, Brazil; F: Colombia; G: SE Brazil; $N$ : sample size; $h$ : number of haplotypes; $\pi$ : nucleotide diversity; Hd: Haplotype diversity (SD: Standard deviation); $k$ : average number of pairwise differences; $F_{\mathrm{s}}$ : Fu's $F_{\mathrm{S}}$ statistic; $F^{*}$ : Fu and Li $F$ test; $D^{*}$ :

Fu and Li's $D$ test; $D_{T}$ : Tajima's $D ; R^{2}$ : Ramos-Onsins \& Rozas $R^{2}$ test. ${ }^{*} p<0.05 ;{ }^{* *} p<0.02 ;{ }^{* * *} p<0.001$. 


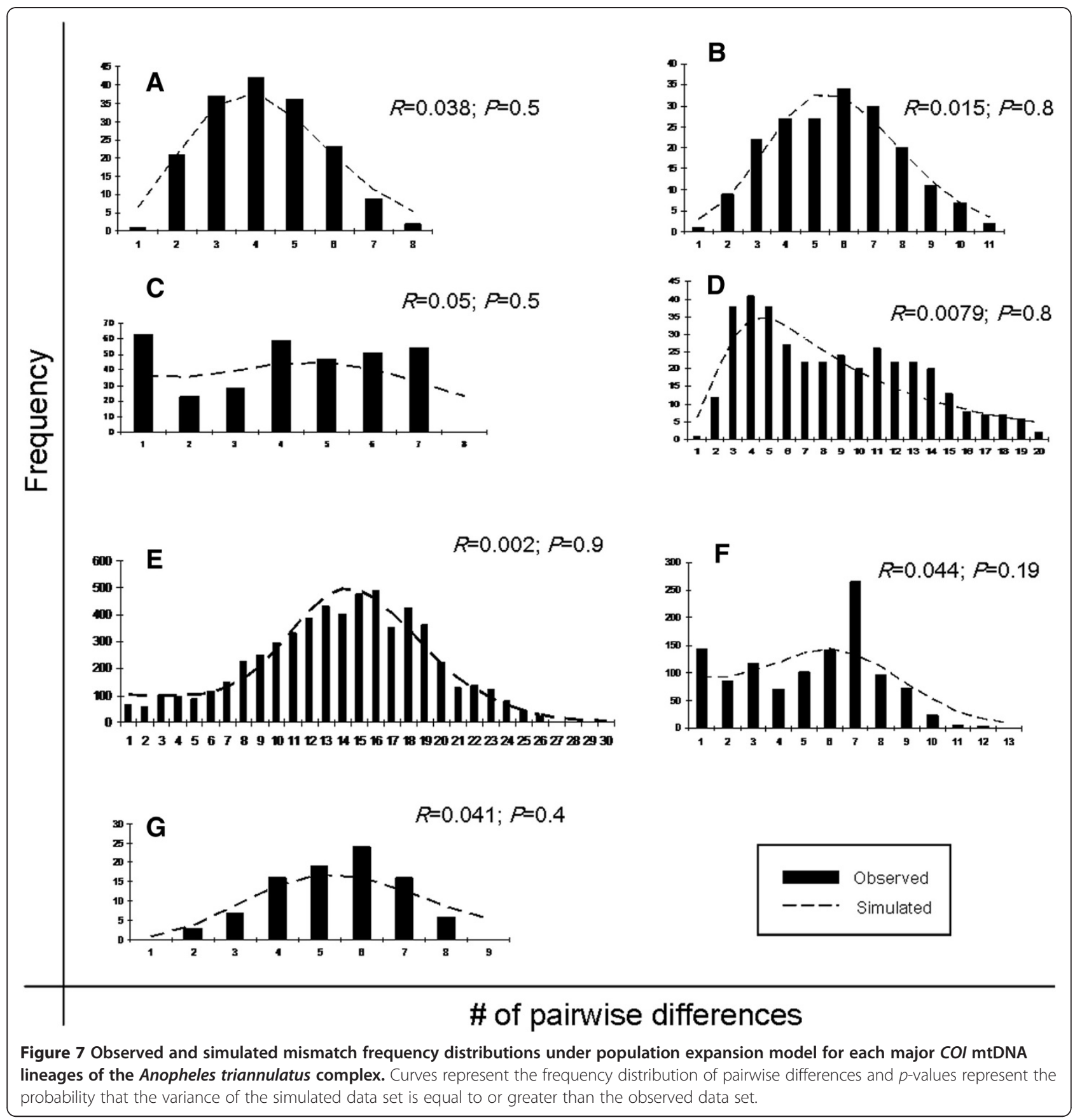

speciation or substantial isolation and divergence among populations. The most common process of mosquito speciation has been considered to be the allopatric mode ([72] and references therein). Although the Amazon delta has been hypothesized as a natural barrier for populations of An. triannulatus and An. darlingi [5,43], in the current study populations of $A n$. triannulatus located on both shores were part of a single lineage with shared haplotypes for both the mitochondrial and the nuclear markers. We performed AMOVA analysis with our data based on the recent findings of Pedro and collaborators [5] to test
Amazonian groups of $A n$. triannulatus. The five groups suggested in the cited study only contributed $21.64 \%$ to the variance, whereas our 3 groupings (TAR + CE + OC; $M G+$ $\mathrm{RJ}+\mathrm{BA}$; and the remaining Amazonian populations yielded a significant variance of $41.27 \%(p<0.01)$.

The high differentiation among populations in the Caribbean Andes region (Colombia-Venezuela, cis-trans Andean) suggests that the Sierra Nevada (west of Lake Maracaibo, Venezuela) acts as a partial barrier to gene flow for COI and white gene, and as a complete barrier for ITS2. The Andean orogeny seems to be responsible 
for this large source of variation, promoting isolation and secondary contact among different lineages in several taxa such as butterflies, birds, bees, sandflies [75], including neotropical anophelines such as $A n$. darlingi [3], An. albimanus [76] and An. nuneztovari [43]. Furthermore, the bimodal COI mismatch distribution for all Venezuelan populations supports the hypothesis of two independent migration events [77]. The current study identified the Serranía de Perija in the Eastern Andes cordillera (between Venezuela and Colombia) as a porous genetic barrier to An. triannulatus, with some mtDNA haplotypes shared as well as some white gene exchange between cis-trans Andean populations. The ITS2 marker depicted the eastern Sierra Nevada Venezuelan populations as more closely related to those from Brazil, Ecuador and Bolivia.

Taking into account lineage divergence estimates in this study, climatic changes during the Pleistocene could have influenced this isolation, creating refugia on both sides of the mountains [2], and might explain better the lineage distributions than vicariant events associated with the older uplift of the North Western Andes (from Late Cretaceous to Holocene) [78]. The absence of shared COI haplotypes may indicate lack of gene flow between some of the lineages. Although the Mantel test showed a positive significant IBD pattern in this area, the results may be confounded by the recent expansion events [79].

In southern South America, the Coastal Mountain Range in SE Brazil promotes population structure in An. darlingi [80], and incipient speciation in Anopheles cruzii [81]. In fact, an extra-Andean glaciation event led to a Pleistocene refugium in Mount Itatiaia and the Serra do Mar [82]. Restricted gene flow and genetic structure of $A n$. triannulatus COI lineage G in this region support a common phylogeographic pattern in mosquitoes and in some other similarly distributed species, such as sandflies [83]. An alternative explanation is that the most extensive An. triannulatus lineage $\mathrm{E}$ (Figure 6) could be interpreted as evidence of a Pleistocene range expansion combined with genetic exchange.

Although the origin of the An. triannulatus complex has been hypothesized to be south of the Amazon River [5], probably in the Belém or Tapajós refugia [84], our data provide mixed signals. On one hand, both $\mathrm{COI}$ and white gene coalescent and phylogenetic analyses found the most likely ancestral sequences to be in northwestern South America (Colombia, Panama, and/or Venezuela). On the other hand, the lowest nucleotide diversity values were found in these populations, and higher values in localities from the Amazon Basin. The low $\pi$ value in Panamanian locations has been hypothesized in the malaria vector An. albimanus to be the result of a past bottleneck event followed by a demographic expansion dated approximately
22,000 years ago [85], although recent bottlenecks can also mimic the effects of an expansion [86]. Panamanian populations of An. triannulatus included in the present study seem to have a similar demographic history and estimation dates for the proposed expansion ( 23,000 years ago). Besides, the least polymorphic population may reflect a smaller effective size and relative isolation of a population. However, populations of An. triannulatus from the Amazon Basin seem to be in equilibrium, whereas in those from the Amazon Delta a demographic expansion around 15,043 years ago was detected (426599,387, 95\% CI).

\section{Conclusions}

Many malaria control programs focus on local vector management and the incrimination of species involved in malaria transmission is crucial. Molecular taxonomy can accurately identify malaria vectors [87]. Phylogeography has been informative in assessing historic migration and colonization routes for An. albimanus [88] and can also be used to trace the origin of accidental introductions such as Aedes albopictus [89]. Because An. triannulatus has been reportedly incriminated in malaria transmission in eastern Amazonian Peru and Amazonian Brazil and Venezuela $[24,26,27,90]$ we hypothesize that at least lineage $\mathrm{E}$ is likely a malaria vector.

\section{Additional file}

\section{Additional file 1: Numbers of transitions ( $X$ and $s$ ) and transversions ( $\Delta$ and $v$ ) at each codon position plotted against Tamura-Nei (Tamura and Nei, 1993) genetic distances for the mitochondrial $\mathrm{COI}$ gene. The steeper slope of the transitions in $\mathrm{nt} 3$ suggests no substitution saturation and is evidence for a constant rate of evolution.}

\section{Competing interests}

The authors declare they have no competing interests.

\section{Authors' contributions}

MM, SB, WH, JH and SNM participated in the design of the study, performed molecular and genetic analysis and wrote the manuscript. TFSN, JRL, FR, RLO, MAMS, ESB, GNF, RW, YML, MJDJ, YR, MMP, LAG, MMC provided samples used in this study, advised on the analysis and assisted and helped to draft the manuscript. JEC conceived and supervised the study, and assisted in the writing of the manuscript. All authors read and approved the final manuscript.

\section{Acknowledgments}

This project has been financially supported by NIH grant AI ROI 54139-02 to JE Conn, PAPES IV Fiocruz-CNPq to RLO, and from the Fundação de Amparo à Pesquisa do Estado de São Paulo, FAPESP (Grant 2011/20397-7 to MAMS), CNPq (BPP no. 301666/2011-3 to MAMS).

\section{Disclaimer}

This research was performed under a Memorandum of Understanding between the Walter Reed Army Institute of Research and the Smithsonian Institution, with institutional support provided by both organizations. The material to be published reflects the views of the authors and should not be construed to represent those of the Department of the Army or the Department of Defense. 


\section{Author details}

${ }^{1}$ New York State Department of Health, Wadsworth Center, Griffin Laboratory, Albany, NY, USA. ${ }^{2}$ Department of Biomedical Sciences, School of Public Health, State University of New York, Albany, NY, USA. ${ }^{3}$ Departamento de Entomología, Instituto Oswaldo Cruz-Fiocruz, Rio de Janeiro, Brazil. ${ }^{4}$ Instituto de Investigaciones Científicas y Servicios de Alta Tecnología, Clayton, Panamá, República de Panamá. ${ }^{5}$ Division of Entomology, Walter Reed Army Institute of Research, Silver Spring, MD, USA. ${ }^{6}$ Departamento de Epidemiologia, Faculdade de Saúde Pública, Universidade de São Paulo, São Paulo, Brazil. ' Superintendência de Controle de Endemias, SUCEN, São Paulo, Brazil. ${ }^{8}$ Department of Biological Sciences, Eastern Illinois University, Charleston, IL, USA. 'Instituto Superior de Entomología "Dr. Abraham Willink", Facultad de Ciencias, Naturales e Instituto Miguel Lillo, Universidad Nacional de Tucumán, Tucumán, Argentina. ${ }^{10}$ Laboratorio de Biologia de Vectores, Instituto de Zoología y Ecología Tropical, Universidad Central de Venezuela, Caracas, Venezuela. "'Instituto Evandro Chagas, Secção de Parasitologia, Belém, Brazil. ${ }^{12}$ Grupo de Microbiología Molecular, Escuela de Microbiología, Universidad de Antioquia, Medellín, Colombia. ${ }^{13}$ Present address: Division Infectious Diseases University of California San Diego, George Palade Labs, School of Medicine, 9500 Gilman Drive, MC 0741,La Jolla, CA 92093, USA.

Received: 26 November 2012 Accepted: 13 February 2013

Published: 22 February 2013

\section{References}

1. Grimaldi D, Engel MS: Evolution of the insects. Cambridge: Massachusetts, Cambridge University Press; 2005.

2. Haffer J: Speciation in Amazonian forest birds. Science 1969, 165:131-137.

3. Conn JE, Mirabello L: The biogeography and population genetics of neotropical vector species. Heredity 2007, 99:245-256.

4. Moritz C, Patton JL, Schneider CJ, Smith TB: Diversification of rainfores faunas: an integrated molecular approach. Annu Rev Ecol Evol Syst 2000, 31:533-563.

5. Pedro PM, Uezu A, Sallum MA: Concordant phylogeographies of 2 malaria vectors attest to common spatial and demographic histories. J Hered 2010, 101:618-627.

6. Loaiza JR, Bermingham E, Sanjur OI, Scott ME, Bickersmith SA, Conn JE: Review of genetic diversity in malaria vectors (culicidae: anophelinae). Infect Genet Evol 2012, 12:1-12.

7. de Queiroz K: Species concepts and species delimitation. Syst Biol 2007, 56:956-974

8. Neiva A, Pinto C: Considerações sobre o gênero cellia theobald, com a descripção de uma nova espécie. Brazil Méd 1922, 36:355-357.

9. Faran ME: Mosquito studies (diptera, culicidae). XXXIV. A revision of the albimanus section of the subgenus nyssorhynchus of anopheles. Contrib Amer Entomol Inst 1980, 15:1-215.

10. Faran ME, Linthicum KJ: A handbook of the Amazonian species of anopheles (nyssorhynchus) (diptera: culicidae). Mosa Syst 1981, 13:1-81.

11. Chadee DD, Wilkerson RC: Anopheles triannulatus (Neiva and pinto): a new anopheles record from Trinidad, west indies. J Am Mosq Control Assoc 2005, 21:316-317.

12. Pinto C: Disseminação da malária pela aviação. Biologia do anopheles gambiae e outros anofelineos no brasil. Mem Inst Oswaldo Cruz 1939, 34:293-430

13. Galvão ALA: Contribuição ao conhecimento dos anofelinos do grupo nyssorhynchus de São paulo e regiões vizinhas (diptera: culicidae). Ara Zool Sao Paulo 1940, 1:399-484

14. Galvão ALA, Lane J: Observações sobre alguns anofelinos de salobra, mato grosso (diptera, culicidae). Rev Biol Hyg 1941, 11:10-18.

15. Deane LM, Causey OR, Deane MP: Chave ilustrada para a identificação de ovos de trinta espécies de anofelinos brasileiros, com algumas descrições novas. Rev Serv Esp Saúde Públ 1947a, 1:293-308.

16. Deane LM, Causey OR, Deane MP: Chave ilustrada para a identificação de trinta e cinco espécies de anofelinos das regiões nordestina e amazônica do brasil pelos caractéres da fêmea, com notas sobre os transmissores da malária (diptera: culicidae). Rev Serv Esp Saúde Púb 1947b, 1:309-336.

17. Forattini OP: Entomologia médica, Volume 1. São Paulo, Brazil: Univ São Paulo; 1962

18. Rosa-Freitas MG, Lourenço-de-Oliveira R, Pinto JCC, Flores-Mendoza C, Nascimento TFS: Anopheline species complexes in brazil. Current knowledge of those related to malaria transmission. Mem Inst Oswaldo Cruz 1998, 93:651-655.

19. Silva-do-Nascimento TF, Lourenço-de-Oliveira R: Anopheles halophylus, a new species of the subgenus nyssorhynchus (diptera: culicidae) from brazil. Mem Inst Oswaldo Cruz 2002, 97:801-811.

20. Silva-do-Nascimento TF, Wilkerson RC, Lourenço-de-Oliveira R, Monteiro FA: Molecular confirmation of the specific status of anopheles halophylus (diptera: culicidae) and evidence of a new criptic species within An. Triannulatus in central brazil. J Med Entomol 2006, 43:455-459.

21. Silva-do-Nascimento TF, Pitaluga LD, Peixoto AA, Lourenço-de-Oliveira R: Molecular divergence in the timeless and cpr genes among three sympatric cryptic species of the anopheles triannulatus complex. Mem Inst Oswaldo Cruz 2011, 106:218-222.

22. Silva-do-Nascimento TF, Lourenço-de-Oliveira R: Diverse population dynamics of the three anopheles species belonging to the triannulatus complex (diptera: culicidae). Mem Inst Oswaldo Cruz 2007. 102:975-982.

23. Dixon $\mathrm{K}$, Roberts DR, Llewellyn CH: Contribuição ao estudo epidemiológico da malária em trechos da rodovia transamazônica, brasil. Rev Inst Med Trop São Paulo 1979, 21:287-292

24 Galardo A, Arruda M, D'almeida A, Wirtz R, Lounibus P, Zimmerman R: Malaria vector incrimination in three rural riverine village in the Brazilian Amazon. AmJTrop Med Hyg 2007, 76:461-469.

25. Rosa-Freitas M, Tsouris P, Peterson A, Honorio NA, de Barros FS, de Aguiar DB, Gurgel Hda C, de Arruda ME, Vasconcelos SD, Luitgards-Moura JF: An ecorregional classification for the state of roraima, brazil: the importance of landscape in malaria biology. Mem Inst Oswaldo Cruz 2007, 102:349-357.

26. Tadei WP, Dutary-Thatcher B: Malaria vectors in the Brazilian Amazon anopheles of the subgenus nyssorhynchus. Rev Inst Med Trop S Paulo 2000, 42:87-94.

27. Aramburú GJ, Ramal AC, Witzig R: Malaria re-emergence in the Peruvian Amazon region. Emerg Infec Dis 1999, 5:209-215.

28. Benarroch El: Studies of malaria in venezuela. Am J Hyg 1931, 14:690-693.

29. Deane LM, Causey OR, Deane MP: Notas sobre a distribuição e a biologia dos anofelinos das regiões nordestina e amazônica do brasil. Rev Serv Esp Saúde Públ 1948, 1:827-965

30. Lourenço-de-Oliveira R, Guimarães AE, Arlé M, Silva TF, Castro MG, Motta MA, Deane LM: Anopheline species, some of their habits and relation to malaria in endemic areas of rondônia state, amazon region of brazil. Mem Inst Oswaldo Cruz 1989, 84:501-514.

31. Lourenço-de-Oliveira R, Luz SLB: Simian malaria at two sites in the Brazilian Amazon. II. Vertical distribution and frequency of anopheline species inside and outside the forest. Mem Inst Oswaldo Cruz 1996, 91:687-694

32. Zimmerman RH, Galardo AK, Lounibos LP, Arruda M, Wirtz R: Bloodmeal hosts of anopheles species (diptera: culicidae) in a malaria-endemic area of the Brazilian Amazon. J Med Entomol 2006, 43:947-956.

33. Matson R, Rios CT, Chavez CB, Gilman RH, Florin D, Sifuentes VL, Greffa RC, Yori PP, Fernandez R, Portocarrero DV, Vinetz JM, Kosek M: Improved molecular technique for the differentiation of neotropical anopheline species. AmJTrop Med Hyg 2008, 78:492-498.

34. Avise JC: Phylogeography: The history and formation of species. Massachusetts: Harvard University Press; 2000.

35. Paredes-Esquivel C, Donnelly MJ, Harbach RE, Townson H: A molecular phylogeny of mosquitoes in the anopheles barbirostris subgroup reveals cryptic species: implications for identification of disease vectors. Mol Phyl Evol 2009, 50:141-151.

36. Gutierrez LA, Gomez GF, Gonzales JJ, Castro Ml, Luckhart S, Conn JE, Correa MM: Microgeographic genetic variation of the malaria vector anopheles darlingi (diptera: culicidae) from Cordoba and Antioquia, Colombia. AmJTrop Med Hyg 2010, 83:38-47.

37. Krzywinski J, Besansky NJ: Molecular systematics of anopheles: from subgenera to subpopulations. Annu Rev Entomol 2003, 48:111-139.

38. Bourke BP, Foster PG, Bergo ES, Calado DC, Sallum MA: Phylogenetic relationships among species of anopheles (nyssorhynchus) (diptera, culicidae) based on nuclear and mitochondrial gene sequences. Acto Trop 2010, 114:88-96.

39. Bower JE, Dowton M, Cooper RD, Beebe NW: Intraspecific concerted evolution of the rDNA ITS1 in anopheles farauti sensu stricto (diptera: culicidae) reveals recent patterns of population structure. J Mol Evol 2008, 67:397-411. 
40. Zapata MA, Cienfuegos AV, Quiros OI, Quinones ML, Luckhart S, Correa MM: Discrimination of seven anopheles species from San Pedro de uraba, Antioquia, Colombia, by polymerase chain reaction-restriction fragment length polymorphism analysis of its sequences. AmJTrop Med Hyg 2007 77:67-72.

41. Lunt DH, Zhang DX, Szymura JM, Hewitt GM: The insect cytochrome oxidase I gene: evolutionary patterns and conserved primers for phylogenetic studies. Insect Mol Biol 1996, 5:153-165.

42. Mirabello L: Molecular population genetics of the malaria vector anopheles darlingi throughout central and south America using mitochondrial, nuclear and microsatellites markers. State University of New York at Albany, Biomedical Sciences Department: Ph.D. thesis; 2007.

43. Mirabello L, Conn JE: Population analysis using the nuclear white gene detects Pliocene/Pleistocene lineage divergence within anopheles nuneztovari in south America. Med Vet Entomol 2008, 22:109-119.

44. Li C, Wilkerson RC: Identification of anopheles (nyssorhynchus) albitarsis complex species (diptera: culicidae) using rDNA internal transcribed spacer 2-based polymerase chain reaction primers. Mem Inst Oswaldo Cruz 2005, 100:495-500.

45. Hall TA: BioEdit: a user-friendly biological sequence alignment editor and analysis program for windows 95/98/NT. Nucl Acids Symp Ser 1999, 41:95-98.

46. Posada D: JModelTest: phylogenetic model averaging. Mol Biol Evol 2008 25:1253-1256.

47. Huelsenbeck JP, Ronquist F: MRBAYES: Bayesian inference of phylogenetic trees. Bioinformatics 2001, 17:754-755.

48. Brandley MC, Schmitz A, Reeder TW: Partitioned Bayesian analyses, partition choice, and the phylogenetic relationships of scincid lizards. Syst Biol 2005, 54:373-390.

49. Librado P, Rozas J: DnaSP v. 5: a software for comprehensive analysis of DNA polymorphism data. Bioinformatics 2009, 25:1451-1452.

50. Dupanloup I, Schneider S, Excoffier L: A simulated annealing approach to define the genetic structure of populations. Mol Ecol 2002, 11:2571-2581.

51. Excoffier L, Smouse PE, Quattro JM: Analysis of molecular variance inferred from metric distances among DNA haplotypes: application to human mitochondrial DNA restriction data. Genetics 1992, 131:479-491.

52. Jensen $J$, Bohonak AJ, Kelley ST: Isolation by distance, web service. BMC Genet 2005, 6:13. v.3.16.

53. Ersts PJ: Geographic distance matrix generator (version 1.2.3): American Museum of Natural History, Center for Biodiversity and Conservation; http:// biodiversityinformatics.amnh.org/open_source/gdmg.

54. Smouse PE, Long JC, Sokal RR: Multiple regression and correlation extensions of the mantel test of matrix correspondence. Syst Zool 1986, 35:627-632

55. Bandelt HJ, Forster $P$, Röhl A: Median-joining networks for inferring intraspecific phylogenies. Mol Biol Evol 1999, 16:37-48.

56. Templeton AR, Crandall KA, Sing CF: A cladistic analysis of phenotypic associations with haplotypes inferred from restriction endonuclease mapping and DNA sequence data III. Cladogram estimation. Genetics 1992, 132:619-633.

57. Clement M, Posada D, Crandall KA: TCS: a computer program to estimate gene genealogies. Mol Ecol 2000, 9:1657-1660.

58. Powell JR, Caccone A, Amato GD, Yoon C: Rates of nucleotide substitution in drosophila mitochondrial DNA and nuclear DNA are similar. Proc Natl Acad Sci USA 1986, 83:9090-9093.

59. Heckel G, Burri R, Fink S, Desmet JF, Excoffier L: Genetic structure and colonization processes in European populations of the common vole, microtus arvalis. Evolution 2005, 59:2231-2242

60. Brower $\mathrm{AV}$ : Rapid morphological radiation and convergence among races of the butterfly heliconius erato inferred from patterns of mitochondrial DNA evolution. Proc Natl Acad Sci USA 1994, 91:6491-6495.

61. Excoffier L, Laval G, Schneider S: Arlequin ver. 3.0: an integrated software package for population genetics data analysis. Evol Bioinform 2005, 1:47-50.

62. Sallum MAM, Schultz TR, Foster PG, Aronstein K, Wirtz RA, Wilkerson RC: Phylogeny of anophelinae (diptera: culicidae) based on nuclear ribosomal and mitochondrial DNA sequences. Syst Entomol 2002, 27:361-382.

63. Gleeson DM, Rowell DM, Tait NN, Briscoe DA, Higgins AV: Phylogenetic relationships among onychophora from Australasia inferred from the mitochondrial cytochrome oxidase subunit I gene. Mol Phylogenet Evol 1998, 10:237-248.

64. Xia X, Xie Z, Salemi M, Chen L, Wang Y: An index of substitution saturation and its application. Mol Phylogenet Evol 2003, 26:1-7.
65. Castelloe J, Templeton AR: Root probabilities for intraspecific gene trees under neutral coalescent theory. Mol Phylogenet Evol 1994, 3:102-113.

66. Nylander JAA, Ronquist F, Huelsenbeck JP, Nieves Aldrey JL: Bayesian phylogenetic analysis of combined data. Syst Biol 2004, 53:47-67.

67. Root FM: Studies on Brazilian mosquitoes. I. Anophelines of the nyssorhynchus group. Am J Hyg 1926, 6:684-717.

68. Krzywinski J, Besansky NJ: Frequent intron loss in the white gene: a cautionary tale for phylogeneticists. Mol Biol Evol 2002, 19:362-366.

69. Merritt TJ, Young CR, Vogt RG, Wilkerson RC, Quattro JM: Intron retention identifies a malaria vector within the anopheles (nyssorhynchus) albitarsis complex (diptera: culicidae). Mol Phylogenet Evol 2005, 35:719-724.

70. Avise JC: Molecular markers, natural history, and evolution. Massachusetts: Second ed Sinauer; 2004

71. Moore WS: Inferring phylogenies from mtDNA variation: mitochondrial gene trees versus nuclear gene trees. Evolution 1995, 49:718-726.

72. Morgan K, O'Loughlin SM, Mun-Yik F, Linton YM, Somboon P, Min S, Htun PT, Nambanya S, Weerasinghe I, Sochanta T, Prakash A, Walton C: Molecular phylogenetics and biogeography of the neocellia series of anopheles mosquitoes in the oriental region. Mol Phylogenet Evol 2009, 52:588-601.

73. Dyer NA, Lawton SP, Ravel S, Choi KS, Lehane MJ, Robinson AS, Okedi LM, Hall MJ, Solano P, Donnelly MJ: Molecular phylogenetics of tsetse flies (diptera: glossinidae) based on mitochondrial (COI, 16S, ND2) and nuclear ribosomal DNA sequences, with an emphasis on the palpalis group. Mol Phylogenet Evol 2008, 49:227-239.

74. Hebert PDN, Cywinska A, Ball SL, deWaard JR: Biological identifications through DNA barcodes. Proc R Soc Lond B Biol Sci 2003, 270:313-321.

75. Arrivillaga JC, Norris DE, Feliciangeli MD, Lanzaro GC: Phylogeography of the neotropical sand fly lutzomyia longipalpis inferred from mitochondrial DNA sequences. Infect Genet Evol 2002, 2:83-95.

76. Molina-Cruz A, de Mérida AM, Mills K, Rodríguez F, Schoua C, Yurrita MM Molina E, Palmieri M, Black WC 4th: Gene flow among anopheles albimanus populations in central America, south America, and the Caribbean assessed by microsatellites and mitochondrial DNA. AmJTrop Med Hyg 2004, 71:350-359.

77. Hasan AU, Suguri S, Fujimoto C, Itaki RL, Harada M, Kawabata M, Bugoro H, Albino B, Tsukahara T, Hombhanje F, Masta A: Phylogeography and dispersion pattern of anopheles farauti senso stricto mosquitoes in Melanesia. Mol Phylogenet Evol 2008, 46:792-800.

78. Gregory-Wodzicki KM: Uplift history of the central and northern Andes: a review. Geolog Society Am Bull 2000, 112:1091-1105.

79. Telles MPC, Diniz-Filho JAF: Multiple mantel tests and isolation by distance, taking into account long-term historical divergence. Gen Mol Res 2005, 4:742-748.

80. Pedro P, Sallum MAM: Spatial expansion and population structure of the neotropical malaria vector, anopheles darlingi. Biol J Linnean Soc 2009, 97:854-866

81. Rona LD, Carvalho-Pinto CJ, Peixoto AA: Molecular evidence for the occurrence of a new sibling species within the anopheles (kerteszia) cruzii complex in south-east brazil. Malaria J 2010, 26:9-33.

82. Müller P: Die herpetofauna der insel von São sebastião (brasilien). Saarbrücken: Verlag Saarbrücker Zeitung; 1968:1-82.

83. Queiroz Balbino V, Coutinho-Abreu IV, Sonoda IV, Melo MA, de Andrade PP, de Castro JA, Rebêlo JM, Carvalho SM, Ramalho-Ortigão M: Genetic structure of natural populations of the sand fly lutzomyia longipalpis (diptera: psychodidae) from the Brazilian northeastern region. Acta Trop 2006, 98:15-24.

84. Prance GT: Forest refuges: evidence from woody angiosperms. In Biological diversification in the tropics. Edited by Prance GT. New York, USA: Columbia University Press; 1982:137-157.

85. Loaiza JR, Scott ME, Bermingham E, Rovira J, Conn JE: Evidence for Pleistocene population divergence and expansion of anopheles albimanus in southern central America. AmJTrop Med Hyg 2010, 82:156-164

86. Tajima F: Statistical-method for testing the neutral mutation hypothesis by DNA polymorphism. Genetics 1989, 123:585-595.

87. Cienfuegos AV, Rosero DA, Naranjo N, Luckhart S, Conn JE, Correa MM: Evaluation of a PCR-RFLP-ITS2 assay for discrimination of anopheles species in northern and western Colombia. Acta Trop 2011, 118:128-133.

88. Loaiza JR, Scott ME, Bermingham E, Sanjur OI, Wilkerson R, Rovira J, Gutiérrez LA, Correa MM, Grijalva MJ, Birnberg L, Bickersmith S, Conn JE: Late Pleistocene environmental changes lead to unstable demography 
and population divergence of anopheles albimanus in the northern neotropics. Mol Phylogenet Evol 2010, 57:1341-1346.

89. Urbanelli S, Bellini R, Carrieri M, Sallicandro P, Celli G: Population structure of aedes albopictus (skuse): the mosquito which is colonizing Mediterranean countries. Heredity 2000, 84:331-337.

90. Gabaldon A, Cova Garcia P: Zoogeografia de los anofelinos en Venezuela: I. Los dos vectores secundarios y los no vectores. Tijeretazos Sobre Malar 1946, 10:78-127.

doi:10.1186/1756-3305-6-47

Cite this article as: Moreno et al:: Phylogeography of the neotropical

Anopheles triannulatus complex (Diptera: Culicidae) supports deep

structure and complex patterns. Parasites \& Vectors 2013 6:47.

\section{Submit your next manuscript to BioMed Central and take full advantage of:}

- Convenient online submission

- Thorough peer review

- No space constraints or color figure charges

- Immediate publication on acceptance

- Inclusion in PubMed, CAS, Scopus and Google Scholar

- Research which is freely available for redistribution 